\title{
Junks to Mare Clausum: China-Maluku Connections in the Spice Wars, $1607-1622$
}

\author{
GUANMIAN XU \\ E-mail: victorhsusea@gmail.com
}

\begin{abstract}
Much more globally entangled than many global historians used to think, the so-called Spice Wars were not only a story of European expansion and Southeast Asian interaction, but had an inextricable northern link leading all the way to China. From the capture of a Chinese junk serving the Spaniards in Ternate by Cornelis Matelief in 1607, to the completion of the first manuscript of the incense compendium (Xiangsheng) by Zhou Jiazhou in Jiangnan in 1618, and eventually to the proposal of the strange monopoly policy by Jan Pieterszoon Coen to the Heeren XVII (Gentlemen Seventeen) in the Dutch Republic in 1622, these seemingly irrelevant events are in fact the fragments of an untold global history of cloves which was not westward bound to the Indian Ocean, the Middle East, and Europe, but northward linked with the East Asian world via the Manila route.
\end{abstract}

Keywords: cloves, Ternate, VOC, Chinese incense culture, Selden Map

\section{Introduction}

In early modern history, the waters surrounding some tiny islands in the eastern part of the Indonesian Archipelago were an arena of global contest. As the only place where cloves, nutmeg, and mace were produced, these islands not only attracted merchants from all over Monsoon Asia, but also European traders from half a globe away. The Portuguese, the Spaniards, the English, and the Dutch all equipped fleets to (semi-) circumnavigate the world via different routes in order to approach these islands to obtain the spices, and to prevent others from obtaining them. Their rivalry gradually spiralled and eventually led to a series of colonial wars in the early seventeenth century, when the newly incorporated Dutch United East India Company (the Vereenigde Oostindische Compagnie, VOC) sought to fully monopolise the entire spice trade. Eventually, by eliminating all European and local 
competitors, the VOC could declare hegemony in the 1660s and from then jealously kept these waters closed to foreign traders until the end of the next century. ${ }^{1}$

The global history of the spices is interesting for the European rivalry, but the Asian connection is no less fascinating. Asian trading in Malukan spices existed long before the arrival of European powers, and survived and continued to flourish during the colonial period. ${ }^{2}$ This article is not the first to have problematised the Eurocentric global history of spices. Beginning with J. C. van Leur and B. Schrieke, generations of scholars have devoted themselves to the study of Asian connections. ${ }^{3}$ By scrutinising numerous reports about "smuggling" activities in European colonial archives, researchers have elucidated how European colonial powers, such as the Portuguese and Dutch, were restrained by their resources, so that Asian traders succeeded in finding myriad ways to circumvent their surveillance. ${ }^{4}$

Nevertheless, the Asian links with the Spice Islands remain elusive because of the relative scarcity of Asian sources. Consequently, only the areas within European influence in South and Southeast Asia have been relatively well studied. ${ }^{5}$ About the spice trade with East Asia, an area beyond the scope of early modern European expansion, much less is known, even though some scholars with a background in Chinese studies have carried out some pioneering work. They point out that Chinese sources indicate there existed a northern route for cloves extending from Maluku all the way to East Asia. ${ }^{6}$ However, their systematic survey mostly ends with the arrival of the Portuguese in the early sixteenth century. ${ }^{7}$ The ensuing encounter between the Chinese network and the European expansion remains largely unexplored.

A close analysis of that encounter will necessitate the cross-examination of European and Chinese sources. In doing so, we should first be mindful that the nature of Chinese sources differs fundamentally from the sources in the European colonial archives. That difference necessitates different approaches. By the standard of economic history, the scanty Chinese trading records authored by literati who happened to have some fleeting interest in the remote regions overseas are much less informative than the institutionally preserved archives of the European overseas trading companies. By exploring the potential of Chinese sources, this article will introduce a cultural perspective that brings new sources, such as the writings concerning the idiosyncratic Chinese incense culture, into the scope of global spice history.

Combining the historiography discussed so far, three types of sources will be examined in this research: European sources on Chinese activities in Maluku; Chinese sources on Chinese maritime trade with Maluku; and Chinese sources on Chinese consumption of Maluku spices in China. By juxtaposing these sources, this research aims to bring these fragments of globalisation together and to reconstruct the China-Maluku connections during the spice wars from three aspects: the Chinese in Maluku, trade between Maluku and China, and Malukan spices in China.

For the purpose of closely examining these aspects within the space of an article (instead of a book), this study chooses to focus on a critical period in the Spice Wars: 1607-1622. At the beginning of that period, the Dutch and the Spanish fought inconclusive battles against each other and occupied different parts of the clove-producing islands in Maluku. By the end of this period, the VOC under the authoritarian leadership of Jan Pieterszoon Coen had apparently gained the upper hand and began to enforce a 
monopolistic policy which aimed to create a mare clausum (closed sea) by excluding all competitors. ${ }^{8}$ But, as will be pointed out, Chinese activities in this region were not only partly tolerated by both Spaniards and Dutch, but actually became an indispensable element for the survival and success of European powers in this region. ${ }^{9}$

Against this backdrop, the question may be raised as to what extent the Chinese link with Maluku played a role in the history of the Spice Wars in particular and to the global spice history in general, and why. The article is organised into five sections. It begins with the discussion of the consumption of the most important Malukan spices, cloves, in China. Then, it shows the route from China to the Maluku. Thereafter, the third section elaborates how the Chinese co-opted the Dutch-Iberian confrontation in Maluku and attained surprising mobility by trading with both of them. The last two sections focus on Dutch sources by showing how the continuous coming and going of Chinese ships in the Maluku region stirred far-reaching ripples within the Dutch colonial system and triggered a series of changes within the Dutch monopolistic policy.

\section{Southern Aroma: Cloves in Chinese Smell Culture}

The history of spices in China is still a largely unexplored field. A quintessential problem is that even identifying a proper Chinese term for "spices" in a historical context is a daunting task. Françoise Sabban suggests that in the food regime, the term "spices" can be best translated as liaowu 料物, which means certain kinds of condiments including scallions, ginger, vinegar, pepper, coriander, tangerine peel, and so on. ${ }^{10}$ But that enumeration is far from exhaustive, because a large number of exotic aromatics, including cloves and nutmegs, fall outside that category. ${ }^{11}$ This disjuncture, in my opinion, is owing to the fact that in Chinese material culture, a large part of exotic spices are not consumed for eating but smelling.

The Song period (960-1279 CE) witnessed a golden age of these exotic aromatics in Chinese smell culture. They became an integral part of the literati's self-styled life. A new genre of writing from the Song period, the compendia of incenses, attests how delicately and pervasively the sleeping, living, and reading spaces of the contemporary scholarofficials were perfumed by aromatics, which were either burned in incense burners or carried in sachets. ${ }^{12}$ In the same period, these aromatics also became an essential part of Chinese medicine. The Song imperial-state for its own ideological and fiscal concerns actively organised the collations and publications of medical formularies. ${ }^{13}$ Via these formularies in general and the Imperial Pharmacy's Formulary (jufang 局方) in particular, the consumption of exotic aromatics as medicine was promoted by the imperial regime. ${ }^{14}$

Cloves were an important part of that story. Along with aloeswood (agarwood), sandalwood, frankincense, and Borneo camphor, cloves were among the most frequentlymentioned exotic aromatics in contemporary incense and medical formulae. ${ }^{15}$ Their popularity was a result of the long-term appropriation of exotica into Chinese material culture since the first millennium. ${ }^{16}$ In that process, cloves earned a unique reputation as the most efficacious breath-freshener, and a well-known anecdote goes that some high-ranking officials were required to put cloves in their mouths when addressing the Emperor during the Later Han Dynasty $(25-220 \mathrm{CE}) .{ }^{17}$ Into the Song period, more medical and practical 
functions had been accredited to cloves. In the officially compiled materia medica of Song, there is already a lengthy description for cloves. The most essential medical property is synopsised as "pungent and warm, non-toxic, to warm spleen and stomach, to cure sudden intestinal turmoil and bloat, various kinds of wind swelling, and tooth cavity." By the end, it specifically emphasises that cloves can "release various kinds of fragrance." "18

Cloves figured even in an illustrated national medicinal survey of the eleventh century. ${ }^{19}$ In that survey, the local officials in Canton commissioned a drawing of the plant of a simulacrum of cloves, the so-called Canton cloves, for the Bureau for Revising Medical Texts of the Northern Song dynasty. That Bureau adopted that image and published it in an illustrated materia medica (Bencao tujing 本草圖經), which in turn shaped Chinese visual understanding of cloves for centuries to come

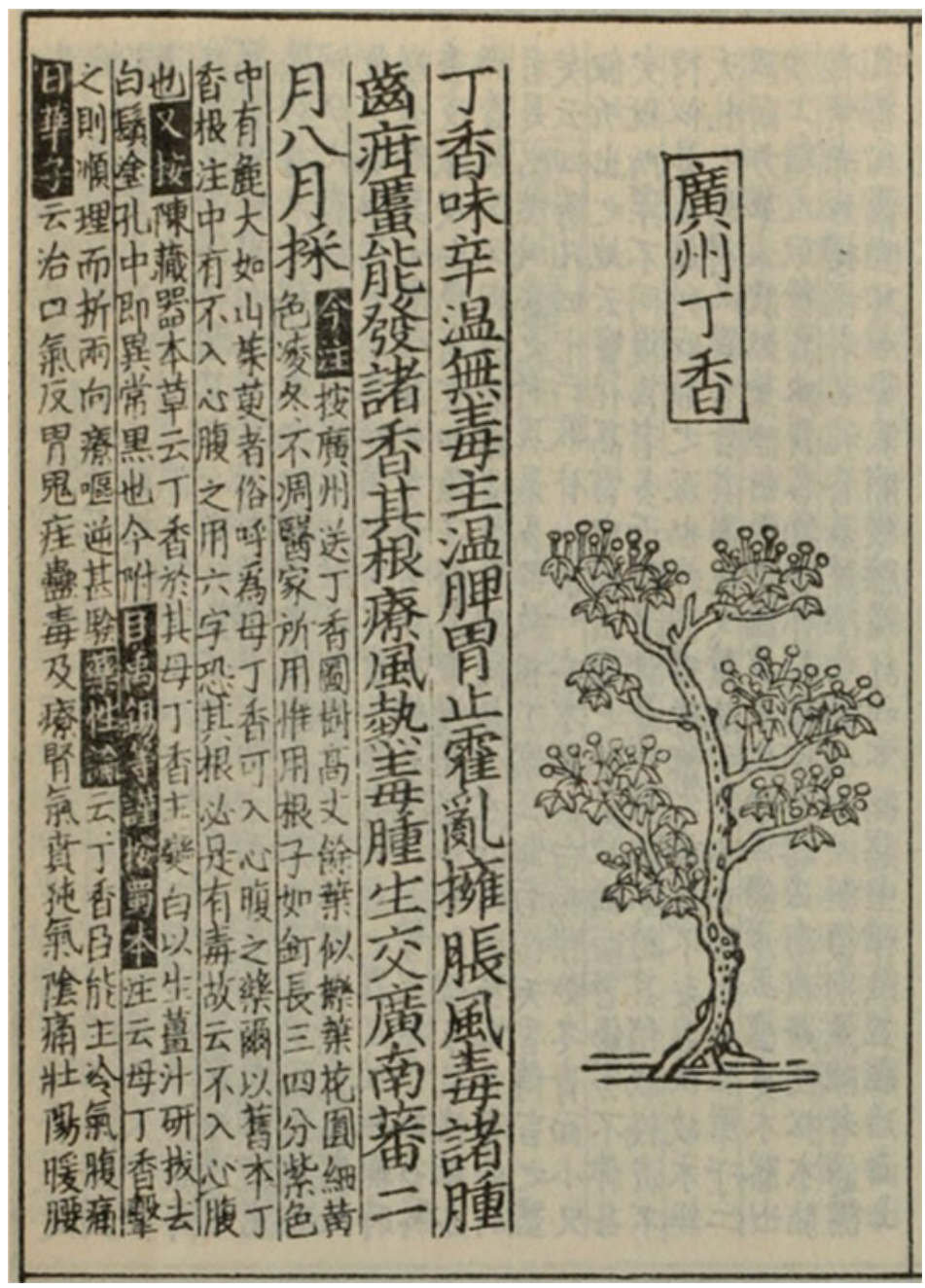

Figure 1. The illustrated Canton cloves $(1249 \mathrm{CE}){ }^{21}$ 
(Figure 1). This phenomenon deserves further research since cloves were not the only case in which the Canton local authorities visually represented simulacra of exotica and claimed their pseudo-origins in Canton. ${ }^{20}$

The Mongol Empire inherited the medical policy of the Song and set up more widespread Imperial Pharmacies in the local level. ${ }^{22}$ Concurrently, the Imperial Pharmacy's Formulary, in which aromatics abound, remained highly popular, so that a famous contemporary doctor, Zhu Zhenheng 朱震亨 (1281-1358), reprimanded that it "has become a fashion. ${ }^{23}$ This period, as Ptak has appointed out, was in fact a high period in China-Maluku connections, as Chinese sources explicitly indicate some traders from China made annual trips to Maluku for cloves. ${ }^{24}$

A decline, as Ptak has observed, was experienced in the early and middle Ming period (ca. 1370s-1550s) ${ }^{25}$ The scope and causation of that decline deserves further research. Here I can only indicate a number of potential links. In general the Ming Empire was much less keen to promote the Imperial Pharmacy system than the preceding Song-Mongol dynasties. ${ }^{26}$ Many Imperial Pharmacies were ignored and became obsolete. ${ }^{27}$ At the same time, the school of Zhu Zhenheng, who was the most outspoken critic of the aromatic-rich Imperial Pharmacy's Formulary and who had explicitly criticised the excessive use of cloves, became immensely popular in the court and among the literati alike. ${ }^{28}$ Its influence likely restrained the medical consumption of exotic aromatics. Moreover, the powerful fleets of the early Ming also ignored the Maluku route, and for this entire period the direct link between China and Maluku was cut off. ${ }^{29}$ It was reported by the Portuguese around the 1540 s, according to local informants, that the Chinese, who "were the first to buy clove wholesale in the islands," had stopped that trade for an immemorial period. ${ }^{30}$

On the other hand, the literati's taste of burning incense and carrying sachet for pleasure and for social distinction was not waning. As noted above, since the Song period, incense had become an integral part of Chinese literati culture and the knowledge of incense consumption had been recorded in a number of compendia of incenses. By the early Ming period, from these compendia, many formulae had been excerpted and copied by some encyclopaedias for daily use (riyong leish $u$ 日用類書). During this period, these encyclopaedias circulated among the literati and functioned as practical manuals for proper householding, in which incense (including the cloves) was a daily necessity. ${ }^{31}$

From the sixteenth century, encyclopaedias for daily use began to be massively and commercially published, with an appeal not only to the literary elites, but to merchants and even commoners. ${ }^{32}$ A good example was The Treatise on Superfluous Things (長物 志 Changwu Zhi) which was compiled by Wen Zhenheng 文震亨 in 1621 and published shortly thereafter. It aimed to propagate an elegant way of collecting and consuming things in a world where the boundary distinguishing the tastes of literati and merchants had already become blurred. In the section on incense, it remarked that only the notable family of the Marquess of Gongshun 恭順侯 could produce the best black and yellow incense cakes in the shape of copper coins, while the other fancy styles sold in incense shops

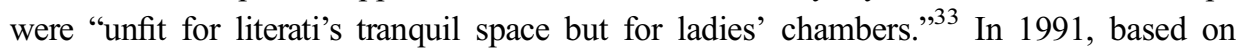
this book, Craig Clunas published his path-breaking research of Chinese material culture. ${ }^{34}$ 
The livelihood of this educated leisure class was supported by the booming economy of the late Ming Empire. ${ }^{35}$ A good example is the life and publication of an incense expert, Zhou Jiazhou 周家贯 (1582-1659 or later). Zhou Jiazhou was born near a bustling commercial hub along the Lower Yangzi River, Yangzhou. ${ }^{36}$ Not far away from Yangzhou was Nanjing, where he sojourned for a long time. ${ }^{37}$ As the southern capital of the Ming Empire, Nanjing hosted a well-reputed publication industry, through which many encyclopaedias and compendia were printed for commercial purposes. ${ }^{38}$ This city also had a plentiful supply of exotica from overseas trade; a cityscape painting of late Ming Nanjing shows a shop offering "a complete range of the goods of the eastern and western oceans." 39

In such a commercial and cultural milieu, Zhou Jiazhou was well received by the literati circle, not because of holding an official position, but for his expertise and connoisseurship in incense consumption and painting framing. ${ }^{40}$ In 1643, Zhou Jiazhou published The Record of Incenses (Xiangsheng 香乘) after decades of collecting, sorting, compiling, and revising (the first manuscript was finished in 1618). ${ }^{41}$ It is the most comprehensive compendium of incenses published in pre-modern China. In its twenty-eight chapters, cloves (including clove twigs and clove bark) figure no less than 295 times. While ubiquitously appearing throughout the entire book, they are most concentrated in chapters 18 and 19. Chapter 18 is titled "Synthesised incenses with floral scent" (ninghe huaxiang 凝合花香), which mean incense concoctions with artificial fragrance resembling the scent of flowers. There are seventy formulae in this chapter. Forty-four formulae have cloves, clove twigs or clove bark as ingredients. Chapter 19 consists of two parts. The first part is titled "Incenses for perfuming clothing" (xunpei zhi xiang 熏佩之香). In the forms of concoction or balm, they can either be placed in sachets, pillows, or even fans, or burned in incense burners, in order to aromatise clothes and bedding. Cloves (including clove twigs and bark) feature in twenty-seven out of its total forty-four formulae. The second part, "Incenses for perfuming body" (tufu zhi xiang 塗傅之香), consists of mixed aromatics which can be directly applied to varied parts of body, such as hair, mouth, face and hand, or be added in bath water. The aromatic mixtures are in the form of powder, balm, or pellets. Cloves (including clove bark) again play a prominent role, as nine out of sixteen formulae in this section have them as ingredients.

In most cases, each formula was precisely regulated. For instance, creating an artificial fragrance of plum blossom required one tael of spikenard (gansong 甘松), one tael of basil (lingling xiang 零陵香), half tael of sandalwood (tanxiang 檀香), half tael of fennel (huixiang 茴 香), one hundred pieces of cloves (dingxiang 丁香), and a little amount of Borneo camphor (longnao 龍腦). These ingredients shall be ground into fine powder (the little amount of Borneo camphor shall be ground separately), and then be mixed with honey and shaped as pellets. These pellets can be burned in incense burners either in a dry or wet condition. ${ }^{42}$

\section{Along the Eastern Sea Route: Chinese Junks to Maluku}

Reading these delicately formulated recipes in which exotic ingredients abound, a question naturally arises: Where did these ingredients come from? In the late Ming period, the 
principal port linking China with the overseas regions was situated in the southeastern coast province of Fujian. In the 1560s, after decades of inconclusive warfare against smuggling private traders, the Ming Empire eventually conceded and legalised private overseas trade. A new county, Haicheng 海澄, was established in the Bay of Amoy (Xiamen). Its county seat, Yuegang 月港 (Moon harbour), was made the stapling port for overseas private trade with Southeast Asia. ${ }^{43}$ By the time when Zhou Jiazhou finished the first draft of his incense book in 1618, Yuegang had already passed its heyday. The over one hundred junks which every year sailed to Southeast Asia with official permits met with fierce competition from unauthorised traders from elsewhere. ${ }^{44}$

Cloves and clove twigs were listed in the custom tariff of Yuegang. According to the regulation of 1589 , the tariff for cloves was 0.18 tael silver per 100 catties, and for clove twigs was 0.02 tael per 100 catties. ${ }^{45}$ This rate was moderate when compared with other important commodities, such as pepper ( 0.25 tael per 100 catties), sandalwood ( 0.5 tael per 100 catties for well-shaped, and 0.24 tael per 100 catties for unshaped), and aloeswood (1.6 taels per 100 catties). ${ }^{46}$ After a universal tax reduction in 1615 , the tariff for cloves was reduced to 0.155 tael per 100 catties and pepper was reduced to 0.215 tael. ${ }^{47}$ The tax rates were generally based on the market value. ${ }^{48}$ It suggests cloves were relatively affordable among myriad exotic goods imported from Southeast Asia.

Cloves were available in various locations in Southeast Asia. Following the Western Sea Route, which extended along the western coast of the South China Sea, Chinese merchants could find cloves in Banten, Aceh, and Champa. ${ }^{49}$ None of these ports really produced cloves locally; they functioned as entrepôts in Asian trading networks, where commodities and peoples from different places converged. From the late fourteenth to middle sixteenth centuries, this kind of transhipment trade was the major conduit of cloves to China. ${ }^{50}$

However, from the 1570s onward, Chinese reappeared in Maluku. During Drake's short visit to Ternate (3-9 November 1579), a Chinese, who proclaimed himself a member of the Ming royal family, showed up and told a fabulous story of how he had been banished from China three years earlier, carrying with him a special mission to collect worthy intelligence for the Ming Emperor (otherwise his return would not be permitted). ${ }^{51}$ Five years later, in 1584, the Spanish reported that "Ternate had only two thousand fighting men but a thousand Javanese, Chinese and Acehnese traders." ${ }^{52}$ In 1589, when the governor of Fujian Province proposed a ship-permit system to allow eighty-eight junks from Yuegang to trade with Southeast Asia each year, a quota was set on the Eastern Sea Route, specifically, for Maluku. ${ }^{53}$

The most illustrative evidence of the rise of the eastern route is from a renowned ocean map, the Selden Map. ${ }^{54}$ This map is anonymous and undated. The only thing we are sure is that the author of Mare Clausum, John Selden, acquired the map from an English commander, as this is recorded in a codicil to Selden's will dated 11 June $1653 .{ }^{55}$ Since its rediscovery in 2008 , the map has aroused a flurry of debate about its origins. ${ }^{56}$ It is now generally accepted that the map was updated after 1607, when the Dutch and Spaniards partitioned Ternate, but before 1624, when the Dutch began to occupy southwestern Taiwan, because the former was represented on the map while the latter not. 


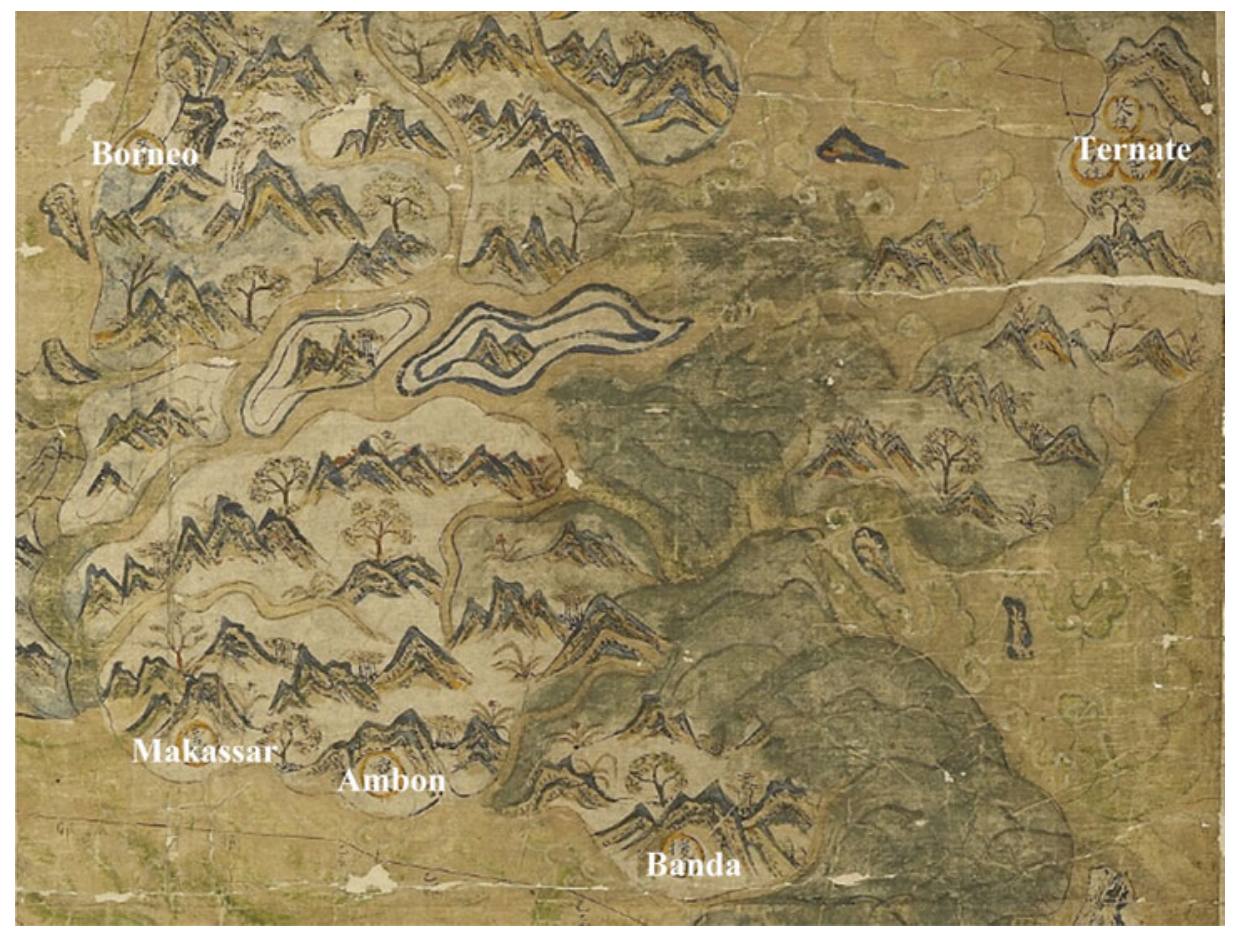

Figure 2. The world of Maluku and its adjacent area on the Selden Map. Bodleian Library, University of Oxford, MS Selden Supra 105. https://seldenmap.bodleian.ox.ac.uk/

On this map, the Spice Islands are distortedly situated on the lower right corner (Figure 2). Zooming in to the islands, one might find that this map is full of mistakes: Ternate is separated from the rest of the Indonesian Archipelago and is at the end of a sea route extending from the north; Timor is situated to the east of Ambon and is placed on Java Island; Makassar and Ambon are located on one and the same big island; and the island of Banda is incommensurately huge.

However, if rolled out completely, this map turns out to be a state-of-the-art sea map for contemporary Chinese navigators: on the top is a compass rose, which is accompanied by a legend; on the sea are crisscrossing sailing routes, which are indicated with compass directions on turning points. Among them are two routes linking the Spice Islands to China (Figure 3). The western route began with Banda and Ambon, from where it extends westwards along the north coast of the Banda Sea and the Java Sea. Once reaching the Riau Islands, it turns north and northeast. Thereafter, it follows the coast of Champa and then turns northeast towards the southeastern coast of the Hainan Island. After passing Hainan, it extends along the coast of China until reaching a haven (likely Yuegang) between Quanzhou and Zhangzhou. The eastern route begins with Ternate, from whence the China-bound ship sails towards the northwest until passing Manila, and then takes a north-northwest course. This route would eventually converge with the western route at Yuegang. 


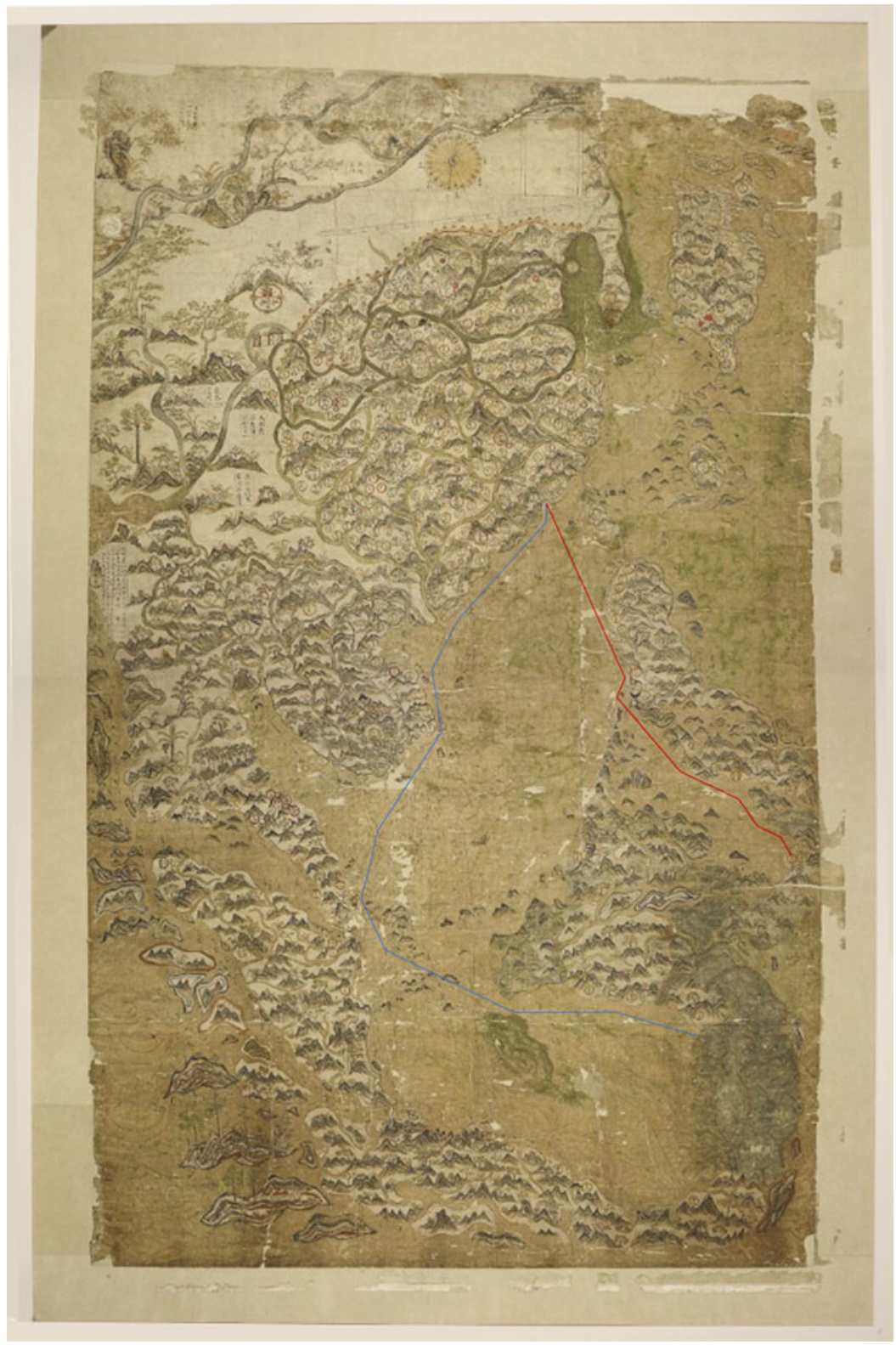

Figure 3. The two navigation routes connecting China and the world of Maluku on the Selden Map.

The critical section in the eastern route to Maluku was from Manila to Ternate. This section is desperately understudied, as it is outside the conventional scope of the Galleon Trade, which focuses almost exclusively on China's connection with the "New World" via Manila while neglecting the role played by the rest of the Philippine Islands. 


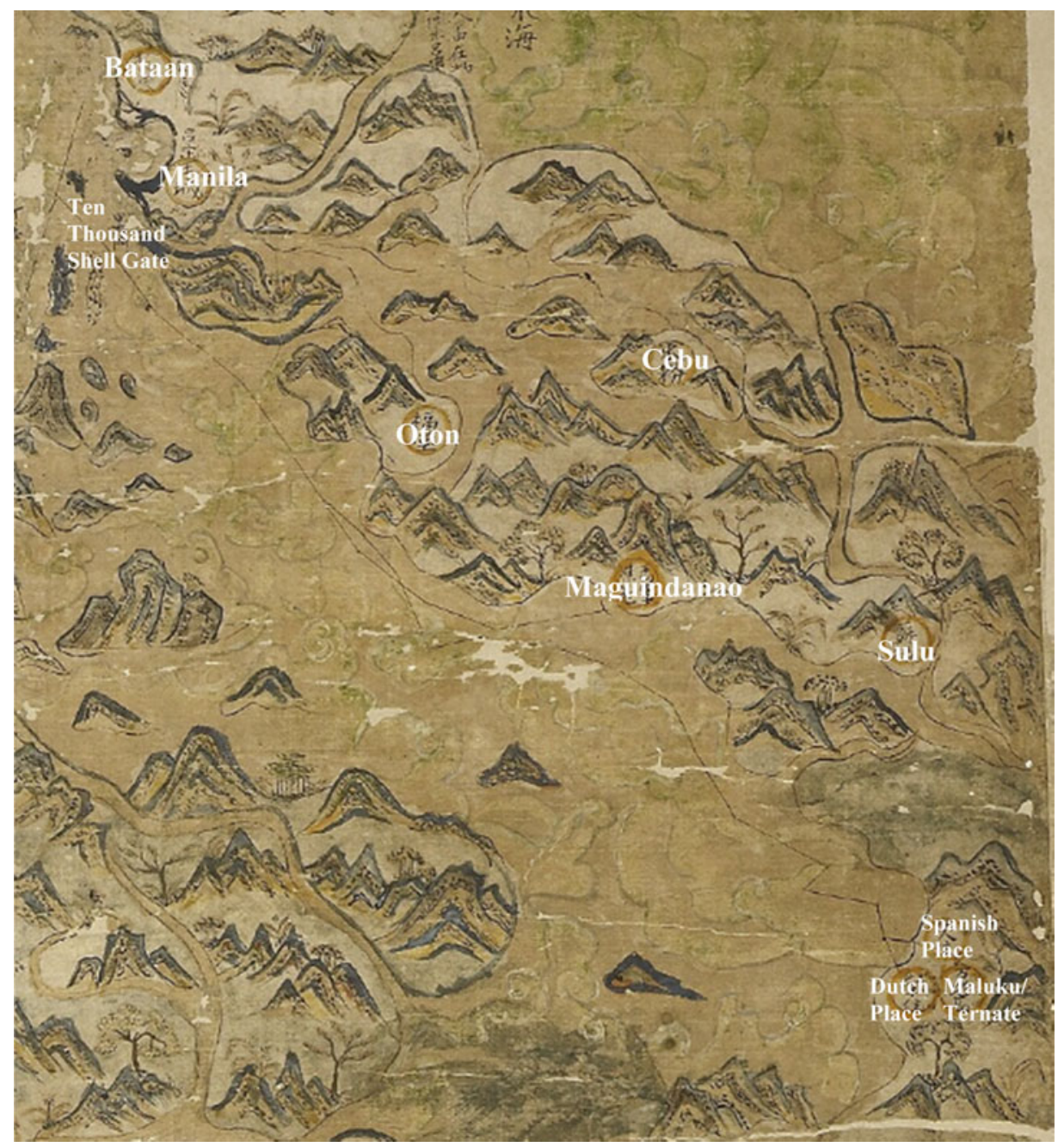

Figure 4. The route and place names between Manila and Ternate (along the Eastern Sea Route) on the Selden Map.

The Selden Map offers some insight on Chinese activities in this ignored region in the early seventeenth century. It shows the map-drawer(s) knew there was a sub-trading system after passing the strait between Mindoro and Palawan (Figure 4). This strait was marked as Ten Thousand Shell Gate (Jiawanmen 甲萬門). Passing the Ten Thousand Shell Gate, there was a route extending to Maguindanao (Majunjiaolao 馬軍礁老) and Ternate/ Gamalama (Wanlaogao 萬老高). ${ }^{57}$ Besides that, the locations of another three trading ports-Oton (Futang 福堂), Cebu (Shuwu 束務), and Sulu (Sulu 蘇祿)—were also indicated, but no exact sailing courses were drawn, and the position of Sulu was also apparent wrong. Yet the mapmaker(s) paid close attention to Ternate by not only showing its location and sailing route, but also pointing out Dutch and Spanish presence on this island. 
However, the Selden Map alone could not guide a Chinese junk all the way from Manila to Ternate, because unlike elsewhere on the map, the sailing routes in this section are not provided with compass directions. To reach Maluku along the eastern route, a Chinese junk skipper needed a rutter, such as the one preserved in the same library as the Selden Map, the Bodleian Library in Oxford, under the title Zhinan zhengfa (指南正法, The true art of pointing south). The main part of this manuscript was most likely compiled around the 1660 s to 1680 s, as it refers to the Zheng Regime in Taiwan (1661-1683) at several places. ${ }^{58}$

This rutter contains sailing guidance to Maguindanao and Ternate. It begins with Mamburao (Wenwulou 文武樓) of Mindoro Island (south outside the Manila Bay). After passing several mountains along the west coast of Mindoro, a junk should sail on a bearing of qianxun (乾巽, $135^{\circ}$ ) for 8 geng (更 watches), namely, 19.2 hours. $^{59}$ Then it will reach the southern tip of Panay Island, which is called Hanjiangqi Mountain (漢降岐山). Thereafter, it will head in the direction of renbin (壬丙, $165^{\circ}$ ) for 9 geng (21.6 hours), and then turns to dansi (單巳, 150 ) for 6 geng (14.4 hours). There, it will reach the northwest coast of Mindanao Island. Following this coast, where "there are many foreign robbers," it arrives at Zamboanga. Passing Zamboange, Maguindanao is on the top of the bay. ${ }^{60}$

It then continues to show the way to Ternate. From a place called Small Xiangyi (小相逸, Small Sangihe?), which is most likely on the bay of Maguindanao, the junk sails on a xunsi bearing (巽巳, $142.5^{\circ}$ ) for 13 geng (31.2 hours) till it sights Jizai Mountain (䯽仔山), which is a huge mountain with five peaks, the taller ones in the east and the lower ones in the west. This mountain must be the Kioto Mountain in southeastern Mindanao. Extending [south] from the Kioto Mountain lies a series of islands, numbered about seven or eight. Among them, there are Guiyu Mountain (龜魚山), Great Xiangyi (大相逸 ${ }^{61}$ Sangihe Besar), and Siau (Shaowu 邵舞). From there, the junk can reach Ternate/Maluku (Figure 5). ${ }^{62}$

Zhinan zhengfa was not the only Chinese rutter which had sailing directions to Maluku. Published as a geographic book in 1618, the Dongxiyang kao (東西洋考, A study of the eastern and western oceans) also collated motley information from contemporary rutters. Its highly abridged records are too fragmentary for reconstructing the exact sailing routes, but still offer some intriguing details on how to approach Ternate via the Sangihe Islands. ${ }^{63}$ It shows that along the way from Maguindanao, a junk will find a place called Qianzizhi Port (千子智港). This port previously belonged to Maluku (Miluoju 米洛居) but was now occupied by Spaniards. ${ }^{64}$ By refering back to the record in Zhinan zhengfa, we know that the Qianzizhi Port must be Kendahe, as Zhinan zhengfa records that Qianzaizhi (千仔致) was on the Island Sangihe Besar. ${ }^{65}$ Not far away from Sangihe Besar, the author of Dongxiyang kao was also aware of the most recent Dutch occupation of Siau. ${ }^{66}$ It records "the freshwater port of Siau is occupied by the red-haired barbarians. ${ }^{, 67}$ After giving this account, it shows "there are four big mountains/islands around this area. After passing them, [you] will enter [the world of] Maluku."68 


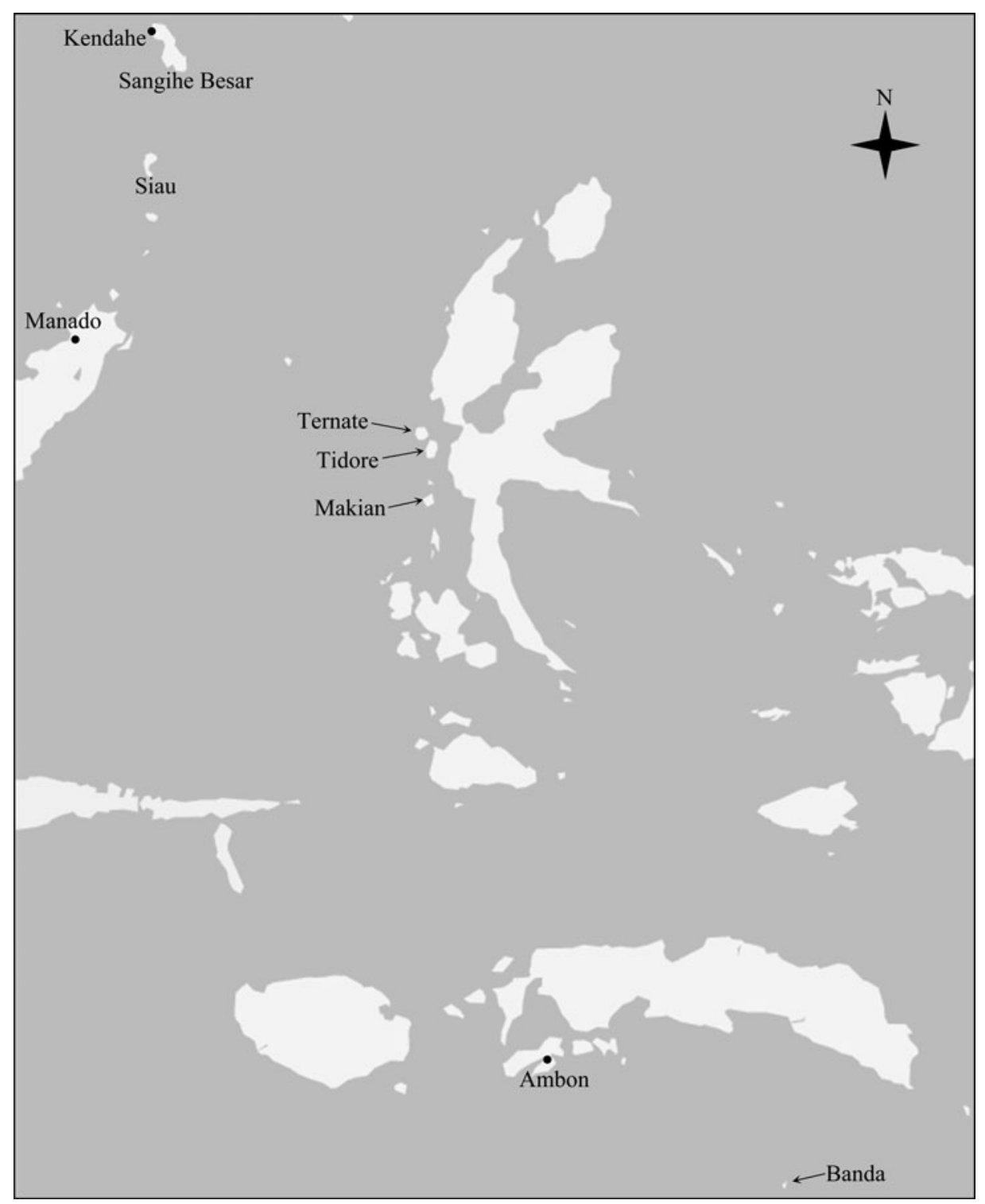

Figure 5. The world of Maluku with place names mentioned in this study.

\section{Two Dragons Sharing One Pool: Trading in Maluku}

In the early seventeenth century, entering the world of Maluku meant entering the epicentre of the spice wars that entangled the entire early modern world. The question is how those Chinese junk traders perceived the rivalry and hostility among European powers, and to what extent they could survive and make a profit on this embattled globalcommodity frontier. 
Testimony about Chinese involvement in the Spice Wars is preserved in the National Archive in Den Haag. It is a justification made by Jacques L'Hermite for the arrest of a Chinese junk around Ternate in $1607 .{ }^{69}$ L'Hermite worked as a secretary in Cornelis Matelief's Asian expedition from 1605 to 1608. In early May 1607, their fleet sailed to Maluku in order to counter Spanish aggression. When the two belligerent powers were at loggerheads in Ternate, some renegades from the Spanish camp crossed over to Matelief and informed him that a Chinese junk serving the Spanish would depart soon. To cut off the enemy's supply, Matelief immediately dispatched a squadron to catch the junk. $^{70}$

The junk was captured and brought to Matelief on 4 June 1607 and its crew were interrogated. ${ }^{71}$ It turned out the skipper carried a contract with the Spaniards, which was signed in Manila. ${ }^{72}$ The contract stipulated that the Chinese junk, a so-called pelo, should supply the Spanish garrisons in Ternate with victuals and cloth, and "75 Chinese craftsmen with all kinds of expertise. ... If he (the skipper) fails to bring these men there, it will be fined amount of [blank not filled in]; and in case he can still bring [blank not filled in] persons, the fine will be reduced in Ternate by the Spanish authority there."73

The mission carried out by this Chinese junk was part of larger Spanish plans to gain control of Maluku. ${ }^{74}$ Since the late sixteenth century, those plans had become imminent, because the Portuguese had been driven out of Ternate by Sultan Babullah (r. 15701583 ) in $1575,{ }^{75}$ and the Union of the Portuguese and Spanish monarchies had been established in 1580. With the aim of repossessing Portuguese forts in Maluku, a series of expeditions were launched from Manila in the $1580 \mathrm{~s}$ and $1590 \mathrm{~s} .^{76}$ All failed and one of them even ended up with the death of the Spanish governor of the Philippines, killed by conscripted Chinese seamen who mutinied en route from Manila to Maluku in $1593 .^{77}$ After dispatching the largest fleet which had ever been seen in Maluku, the Spanish eventually conquered the entire Maluku region in $1606 .{ }^{78}$ Ironically, this seemingly sweeping victory would instead become an enormous burden for the Spanish Empire. After the conquest, it was decided by a royal decree (cedula real) that Maluku would be occupied by Spanish force while the trade of cloves would be preserved for the Portuguese, because the survival of Portuguese India hinged on that trade. ${ }^{79}$ As a result, each year over 230,000 pesos (one peso denominates one "real of eight," referred as "real" below) were drained from Manila for the expenses of the garrison in Maluku alone, ${ }^{80}$ while barely any cloves were shipped back to Manila as return. $^{81}$

Such an exhausting war in the remotest corner of the Spanish Empire offered a rather profitable market for the Chinese. For decades already in Manila, thousands of Chinese traders, artisans, and labourers had been living in the Parian, and supported all aspects of the colonial lives of the Spaniards. ${ }^{82}$ It is not surprising that the Spanish asked the Chinese to ship victuals and cloth and seventy-five craftsmen to Ternate, ${ }^{83}$ aiming to extend their collaboration from Manila to Maluku.

The contract with Manila also secured Chinese trading in the Spanish-controlled sphere of Maluku. In the captured Chinese junk, the Dutch discovered about five hundred 
quintals of cloves, ${ }^{84}$ which the Chinese bought at 6 reals per quintal and had paid $1 / 3$ as tax, 366 reals of cash, $417 / 8$ marck of silver (equal to $3767 / 8$ reals), and 500 pieces of wambuis (a kind of fabric armour). ${ }^{85}$ The junk planned to carry them first to Manila and then back to Zhangzhou, where Yuegang is situated. ${ }^{86}$ Therefore, although the contract with Manila only regulated the amount of money they could receive after performing the contractual obligation, the Chinese traders in fact used part of that income to purchase cloves in Ternate. That trade was also not prohibited by the Spanish garrison there, as long as they paid one-third customs.

After capturing the junk, Matelief was now in a predicament. Although the Chinese junk was serving his Spanish archrivals, China itself was not at war with the Dutch. China was actually imagined to constitute a lucrative market for the Dutch United East India Company (VOC), and had been designated as the next stop for Matelief's fleet. In order to preserve relations with the Chinese trading community, Matelief decided to carry all the Chinese crew of the captured junk to China. Upon arrival in China, they were released. The Chinese skipper was even entrusted with a small amount of money to negotiate a trading deal with the Chinese mandarins in Canton. He was promised that once Chinese authorities agreed to trade with the Dutch, all of his loss in Ternate would be fully compensated.

This event alerted the Chinese trading community back in Yuegang and was reflected in the Chinese narrative of the Spice Wars. Zhang Xie, the author of the Dongxiyang kao published in 1618, attempted to make sense of the Spice Wars in his own way:

Cloves: Along the Eastern Sea Route, only this place $^{87}$ produces [cloves]. The barbarians ${ }^{88}$ use them to exorcise evil spirits. It is said that if they place more cloves in their own countries, their countries will have the kingly vital force (wangqi 王氣). Therefore, these two barbarians ${ }^{89}$ have to compete with each other. ${ }^{90}$

Without knowing the exact use of cloves in Europe, Zhang Xie, as a Chinese literatus, was nevertheless amused by the extraordinary efforts of the Dutch and Spaniards to get hold of the cloves produced on these tiny islands. The best explanation he could offer was that those barbarians had fetishised cloves as the key to acquire vital royal power. This fabulous account was likely well received among the Chinese readership, as it was fully quoted in the Record of Incenses by Zhou Jiazhou, published twenty-five years later, in $1643 .^{91}$

Zhang Xie was also aware of the Chinese involvement in the Spice Wars. Perhaps informed by someone like the Chinese skipper arrested by Matelief, he recounted the peril of trading with the belligerent parties in Maluku:

In previous time, if a Chinese ship carried goods for the Dutch but was intercepted by the Spaniards, the Spaniards would certainly get furious and say "the ship is not coming for us but to assist the Dutch." They would loot the cargo and kill people. Hence, Chinese traders had to keep the cargo secret and to not let the Spaniards see. [Similarly], if the Dutch found the Chinese ship carrying goods for the Spaniards, they will also be furious as such. This situation has been slightly de-escalated after their disputes were mediated. However, like two dragons sharing one pool, it is quite difficult to do business there. ${ }^{92}$ 
Therefore, the balance between the Dutch and the Spaniards was essential to Chinese commerce in Ternate. To trade with both sides, a modus vivendi had to be attained, but how was it achieved? Zhang Xie wrote down an intriguing anecdote, which claims that a Chinese had brokered a ceasefire agreement between the Dutch and the Spaniards:

[The Dutch and the Spaniards] had since then attacked each other [in Ternate] every year with ups and downs on both sides. A Chinese, who was sojourning there, was smart and eloquent. He lobbied between these two countries [and let them agree] to partition the island with the slope of the Mount Gamalama as boundary. The area north to the mount belongs to the Dutch, and the area south to the mount belongs to the Spaniards. [Thereafter] both stop war and co-dominate this island. ${ }^{93}$

The doubtful credibility of this account notwithstanding, what is important here is that it reveals some Chinese were not only trading in Maluku, but were actually sojourning there, and playing some mediating function between the belligerent powers. ${ }^{94}$ In European sources, we can also find that both Dutch and Iberian sides claimed that there were Chinese staying in Maluku and serving their enemies. As discussed at the beginning of this section, the Chinese junk captured by Matelief was initially hired by the Spaniards to import seventy-five Chinese craftsmen to serve the Spanish garrison. ${ }^{95}$ A Portuguese report written in Malacca in 1619 shows there were about two hundred Sangleys, which refers to the Chinese traders coming along the Manila route, staying with the Dutch force in Ternate. ${ }^{96}$ Although serving different European powers, these Chinese were part of the same Chinese network extending all the way from Yuegang to Maluku via Manila. Also through this network, their knowledge about the Spice Wars was transmitted back to China. Zhang Xie wrote it down in his Dongxiyang kao in a digestible way for Chinese literati, who in turn further circulated it in their own literature, such as the Record of Incenses.

\section{Dutch Response and the Making of a Closed Sea}

However, this modus vivendi was not unchallenged. It rather became a major target of criticism by an ambitious young official serving in the Dutch East India Company, Jan Pieterszoon Coen. On 10 November 1614, Coen wrote a letter to the Heeren XVII (Gentlemen Seventeen, the board of the Company based in the Dutch Republic) to complain that a Chinese ship had undermined the Company's fundamental interests in the Spice Islands:

There arrived a Chinese junk with various goods. How harmful it is to the Company at that place! The gentlemen can read clearly from the attached letter by the Director, den Dorst. Before this junk arrived at that place, so many goods had been sent there [Ternate] from here [Banten], and were sold by our people with so great profit that, every month, 2000-3000 reals were received. After the arrival of this junk, all sale stopped. The Governor [Laurens] Reael advises that [this junk] may have carried away 35,000 reals from there. (10 November 1614, sent by ' $\mathrm{T}$ Hart, from Banten 10/11/1614 to Rotterdam 24/04/1615) ${ }^{97}$ 
Such a financial fiasco provided Coen an opportunity to criticise the tolerant policy towards Asian traders by the governor of Maluku, Laurens Reael. ${ }^{98}$ Coen complained in a letter to the Gentlemen Seventeen that "it makes little difference whether the Spaniards take over the [entire] Maluku, or whether other foreigners under the protection of our weapons are doing their business," because "if the foreigners are allowed to trade, then [you] gentlemen will have nothing but the cost of the wars." 99 In the late 1610s, there was a large debate within the Company regarding whether Asian traders should be excluded from the waters of Maluku, Ambon, and Banda (the three major subregions of the Spice Islands). Most high-ranking officials stationed in Asia preferred a lenient policy towards Asian traders because they supplied daily necessities to local people, but Coen, with support from the Gentlemen Seventeen, leaned towards a more draconian policy for securing a complete monopoly. The implementation of the latter policy eventually led to the Banda massacre (1621) and to the creation of a closed sea around the Spice Islands. ${ }^{100}$

The 1614 visit of the Chinese junk can be rendered as a critical point which triggered such a chain of events. To begin with, when writing this report, Coen was still the accountant-general of the VOC and was stationed in Banten, thousands of kilometres away from Maluku. ${ }^{101} \mathrm{He}$ had neither the power to supervise issues on Maluku nor firsthand knowledge of the local situation. Before Coen, the governor of Maluku, Reael, who resided in Fort Orange in Ternate and was closely following this issue, had already submitted two letters to the Gentlemen Seventeen regarding this Chinese junk. The first letter, dated from 20 May 1614, was a brief that "the foreigners' trade, mainly by Chinese" should be inhibited in a proper way as it had become so hindering to the Company's trade. ${ }^{102}$

The second letter, dated from 20 June 1614, sheds more light on what happened on the ground. This Chinese junk was in fact a pelo, the same as the one captured by Matelief in 1607 which had sailed along the Manila route. Upon its arrival in Ternate, it was allowed by the Dutch to set up a shop, and upon its departure, it carried away at least 30,000 or 35,000 reals. According to Reael, this huge amount of money would have been earned by the Company if the Chinese junk had been turned away. Reael also analysed why there was so much money circulating locally in Maluku, which created such an opportunity for the Chinese. The root of the problem was in fact linked to the clove-purchase policy of the Company. Reael claimed that previously the native people in Maluku sold cloves "for nothing else but food and cloth." Since the Company introduced reals as payment for cloves, things began to change. With the cash money earned therefrom, the local people realised they could buy the necessities of life at a much lower price from foreign traders than from the Company. In order to earn more money, they also became less interested in plucking cloves, which were subject to the Company's monopoly, and began to devote more time to fishing and other occupations. Reael proposed to demonetise the local economy by resuming the former Portuguese practice of using cloth instead of money as payment. He believed when there was no money circulating in Maluku, foreign traders would stop coming as there is no return for them. ${ }^{103}$ 
While awaiting a reply from the Gentlemen Seventeen, with whom a round of communication often took two years, a Chinese junk had arrived at Ternate again in May 1615. This time Reael opted to purchase its silk textiles and cloth with the Company's funds. The problem was that the Chinese only accepted payment in ready money, but Fort Orange, the Company's administrative centre in Ternate, was short of cash. On 7 May 1615, Reael, together with his council, made a decision to immediately dispatch a ship to the nearby fort on Makian to procure more money. ${ }^{104}$

That event irked Coen, who had been promoted to director-general (second in command) by the end of 1614. In his letter dated 22 October 1615, Coen first reported the slack sale of cloth in Maluku because of competition from Asian traders. Thereafter he turned to that Chinese junk. "There was again a junk coming from China, which again carried about 30,000 reals away from Maluku. Last year I had really earnestly recommended Reael to repulse those foreigners from Maluku," but the request was not followed up by Reael, because he did not wish to alienate the local people in Ternate. Coen proposed that if the foreigners came to Maluku in search of cash, the Company should pay the salary of garrison soldiers with cloth and to "pay out no cash any more." 105

Reael was not unaware of the exigency caused by the visit of Chinese junks. On 11 September 1615, he convened a council to discuss what action should be taken if another Chinese junk would show up. ${ }^{106}$ After extensive debate, it was concluded that this issue should be pending for further decisions because "a definitive order is so difficult to be made." ${ }^{107}$ A few months later, on 7 April 1616, there came once again a Chinese junk at Ternate. ${ }^{108}$ By then, the reply from the Gentlemen Seventeen was still on the way. ${ }^{109}$ Reael and his council decided to take a prudent action. They refrained from using force but tried to pay the Chinese in cash "as little as practicable." 110

However, in the Dutch Republic, the directors of the Company did not appreciate Reael's effort to maintain the subtly balanced situation in Maluku. What they expected was a complete monopoly, which in their opinion required the creation of a closed sea. On 30 April 1615, merely six days after the arrival of the ship in Rotterdam which carried the letters telling the visit of Chinese junk in 1614, a clear order was given to Coen:

Further to our regret, we understand that, as you write, the Chinese make great damage to us by bringing and selling their cloth in Maluku and Ambon. The vice governor, Reael, advises that the Chinese by this time should have transported 35,000 reals from this place. We believe that we shall prevent this with all possible means, of litigating against them by forms of confiscation or others. Once they arrived, they should be implied to leave immediately. We have the same [opinion] not only of the Chinese, but also of all foreign peoples, such as the Javanese, Malays and Kelings, also those from Makassar, Gresik and other places lying nearby, who come there for trade. (30 April 1615, sent by Swarten Leeuw, from Texel 18/05/ 1615 to Banten 30/04/1616) ${ }^{111}$

A few days later, another letter was issued to Governor-General Gerard Reynst. It extended the prohibition of foreign trade to all foreign traders, including both Asian 
and European. ${ }^{112}$ In other words, the Gentlemen Seventeen explicitly ordered the creation of a closed sea around the Spice Islands by universally excluding all foreign ships.

\title{
Let the Chinese Stay But No Others: Towards a Strange Monopoly
}

When the vessel carrying this order arrived in Banten on 30 April 1616, Governor-General Reynst had passed away, and Reael would soon succeed him. ${ }^{113}$ As revealed by Meilink-Roelofsz, Reael together with his supporters in the Spice Islands opposed the idea of the creation of a closed sea. ${ }^{114}$ On 10 May 1617, Reael made a clear statement to the Gentlemen Seventeen:

\begin{abstract}
In the letter, you give ample order to keep all foreigners, especially the English, French, and others away from Maluku, Ambon, and Banda, with force, but firstly implying [them] nicely. This has already taken place against the English and we have given command to all other places to put this to work as per your order. ... However, concerning putting your order to work against the Kelings, Malays, Javanese and other indigenous foreigners, [we find] our business would be brought into complete confusion and particularly at this juncture when [we] are staggered by our problems with the Spaniards on the one side and with the English on the other. ${ }^{115}$
\end{abstract}

From the perspective of Reael, it was also unjustified to repulse Asian traders from the waters of the Spice Islands. He contended that the local people of Maluku had a contractual obligation to sell cloves exclusively to the Company, but there was no legal base "to allow us to expel all foreigners from their land." "16 Even against the Chinese junks that triggered all these debates, Reael refused to appeal to violence. In the same letter, he reported that the Chinese no longer carried so many goods to Maluku because they had received bad treatment in Maluku, but this could not deter them from arriving, and if they came again, he would "let them stay." 117

Reael's defiance disappointed the Gentlemen Seventeen and facilitated Coen's promotion. This had been anticipated by the Gentlemen Seventeen from the very beginning. In their letter to Coen on 26 November 1616, the Gentlemen Seventeen expressed their discontent with the situation in the Spice Islands, and hoped that Reael would follow Coen's advice. ${ }^{118}$ This irreconcilable discord finally led to the replacement of Reael by Coen. On 25 October 1617, the Gentlemen Seventeen issued a letter appointing Coen as the new governor-general and in addition ordering Coen to send Reael back to the Dutch Republic. ${ }^{119}$ In the same letter, Coen was urged to take immediate actions against the foreign traders in the Spice Islands. ${ }^{120}$

In tandem with these changes, a new decree was promulgated by the end of 1617 . Under the title "Instructie voor den Gouverneur en de Raden van Indië" (Instruction for the governor and the council of India), it regulated a number of policies to expel foreign traders from the Spice Islands, including the use of force, armed surveillance, and the replacement of cash payment with cloth. ${ }^{121}$ To replace the functions of foreign traders, it also attempted to partly legalise private trade by the Company's former employees. According to this decree, only those who had "well and faithfully" completed their service in the Company were eligible to apply for "free trade" in Asia. Their application 
should be made to the governor-general and council of the VOC in Asia. ${ }^{122}$ This so-called "free trade" was considered helpful and necessary, insomuch as they could replace Asian traders to provision Dutch garrisons, and to collect spices for the Company. ${ }^{123}$

That strategy failed quickly. In Ambon, Van der Hagen decried the shortage of good rice caused by the expulsion of Asian traders. It forced the Gentlemen Seventeen to write a letter to Coen on 1 May 1619 with instructions to permit Asian traders importing "very good white rice." ${ }^{24}$ A more alarming report was made by Governor Van Speult, who pointed out that a mutiny was looming among soldiers because of the conversion of payment from cash to cloth. To avoid such a disastrous consequence, the Gentlemen Seventeen recommended that Coen should cautiously deal with this issue and let the soldiers make their own choice between cash and cloth. ${ }^{125}$

Coen, as the advocator of these policies, was now caught in a dilemma, and had to bail himself out. His solution came in an ironic way as the Chinese, whose trade in Maluku was a major cause of these debates, were entrusted by Coen to relieve the Company of the crisis. On 6 September 1622, he wrote to the Gentlemen Seventeen: "If the indigenous traders of the Moluku, Ambon, Banda and other eastern lands could not be repelled, we are of opinion to bring another staple of trade to the castle of Ambon with the help of Chinese trade, upon which [we] also expect to gain good profit, as having already begun." $126 \mathrm{He}$ argued this would be "the right measure to relieve you of the excessive great burden and to assure the status of the Company in India, as you settle the people, who can live as honest and reasonable people, in your colony." 127 Then, Coen explained why the Company's former employees could not be trusted, as they were mostly soldiers and seamen "who are created to fight the waves of the sea and their peers." 128 In fact, instead of being honest traders, some soldiers and seamen turned "free traders" abused the privilege of having weapons and ammunition to plunder Asian traders and behave like pirates. ${ }^{129} \mathrm{He}$ also expressed a prejudice against "the noblemen of Banten, the king of Aceh, these of Surat, Coromandel, Mataram, and all other Moors." ${ }^{130}$ This was linked to Dutch concern for the intricate relations between Muslims and Christians in the Spice Islands. ${ }^{131}$

The view of the Chinese as reliable and industrious collaborators was not invented by Coen. In the letter which appointed Coen governor-general and urged him to take actions against indigenous traders, the Gentlemen Seventeen had already given specific instruction to populate Ambon and Banda with the Chinese. ${ }^{132}$ In the letter "Instruction for the governor and the council of India" we can find words such as "the Chinese are an industrious, hardworking and unarmed people, of who [we] are not to fear. They will never be able to revolt and make themselves as the master of these lands." 133 Therefore, Coen followed an existing discourse and appropriated it to solve his own problem.

The close collaboration between the Company and the Chinese had been in practice before Coen's proposal, largely because of an important Chinese trader, Inpo. According to Blussé's recent research, even earlier than the incorporation of the VOC, Inpo, then a young man, had visited the Dutch Republic in 1600 with a ship of the Company of Middelburg (one of the pre-companies which formed the VOC in 1602) ${ }^{134} \mathrm{He}$ sojourned 
there for one year, learned Dutch, was christened in the Dutch Reformed Church, and left behind a portrait with his notes. ${ }^{135}$ After returned to Asia in 1602, he stayed in Patani to first serve the Company of Middelburg and then the VOC. ${ }^{136}$ In 1605 , he was a key figure who masterminded a Dutch expedition to southern Fujian in order to have direct access to Chinese market. ${ }^{137}$ Although that plan failed, his cordial relation with the Company was invulnerable as he was treated almost like a Dutchman. ${ }^{138}$ Later on, Inpo participated in various actions for the Company, including Matelief's siege of Malacca. ${ }^{139}$ In 1612, when the commerce in Patani was turning downwards, he moved his entire business to Ambon to provision Dutch fortresses there. ${ }^{140}$

Inpo passed away in Ambon in 1614, but the collaborative relationship had been seeded. On 8 December 1619, when the rice shortage in Ambon was reported by van der Hagen, Coen approved the appointment of a Chinese headman in Ambon to let him import rice and Chinese migrants from Makassar. ${ }^{141}$ On 28 February 1620, Coen dispatched a Dutch ship to Bima, Sumbawa, to bring Chinese junks to Ambon, and he promised the Chinese that after their junks arrived at Ambon, they could choose to sail back to China. ${ }^{142}$ Into the middle of the seventeenth century, a bustling Chinese settlement formed in Ambon. ${ }^{143}$

\section{Conclusion}

Much more globally entangled than many historians realised, the so-called Spice Wars were not only a story of European expansion and Southeast Asian interaction, but had an inextricable northern link leading all the way to China. From the arrest of the Chinese junk by Matelief in 1607 to the completion of the first manuscript of the incense compendium (Xiangsheng) by Zhou Jiazhou in 1618 and the publication of the maritime geographic book (Dongxiyang kao) by Zhang Xie in the same year, and eventually to the proposal of the strange monopoly policy by Coen in 1622, these seemingly irrelevant events are in fact the fragments of an untold global history of cloves which was not westward oriented to the Indian Ocean, the Middle East, and Europe, but northward linked with the East Asian world via the Manila route.

Throughout this violent period, marked by the intensification of European rivalry, the China-Maluku connection was hardly impaired. Instead it flourished in the shadow of the European confrontation. The tremendous investment made by both belligerent parties for their garrison troops in Maluku created a lucrative provision market. Hinging on that market, the Chinese traders carefully maintained a subtle balance which allowed them certain mobility to trade with both sides and to carry back not only spices but also specie which was imported by the European powers to fund the Spice Wars. This observation should not surprise us, as the art of being governed had long been cultivated among Chinese traders back in their hometown, Fujian, in their long-term interactions with the coastal defence system of the Ming Empire. ${ }^{144}$

Moreover, initially triggered by the continuous drain of specie by Chinese junks, the Dutch policy towards the creation of a closed sea in the Spice Islands eventually altered 
to be a strange monopoly which favoured the Chinese exclusively. Before that policy, the Chinese traders had to compete with other Asian and European traders in the Spice Islands in order to sell cloth, to earn silver, and to purchase cloves. After the series of changes introduced by Coen and the Gentlemen Seventeen, the Chinese became the only foreign traders who were allowed by the Dutch to sail to the waters of the Spice Islands, to supply Dutch fortifications, and to stay and build their own trading networks, while all others could not. We can render this development as an important step that would eventually lead to the Chinese century in Southeast Asian history. ${ }^{145}$

\section{Acknowledgements}

The author would like to thank Prof. Jos Gommans, Dr. Fan Lin, Prof. Hilde de Weerdt, Prof. Chen Tsung-Jen, Prof. Françoise Sabban, and Prof. Liu Yonghua, who helped the improvement of this article at different stages. Dr. Ton Harmsen, René Wezel, Tristan Moster and Peter van Summeren taught me how to read early modern Dutch sources from the very beginning, and Menno Leenstra pointed out a very important source. I want to express great gratitude to the two anonymous reviewers for their invaluable comments. The help from Prof. Ryan Crewe is most remarkable. He volunteered to offer translated Spanish sources. Last but not least, I am indebted to Prof. Leonard Blussé for his meticulous corrections by the final phase of revision. I am solely responsible for any mistakes.

\section{Bibliography}

\section{Unpublished Primary Sources}

Nationaal Archief of Den Haag (NA)

Het archief van de Verenigde Oost-Indische Compagnie (VOC), 1602-1795(1811) Inventory number: 1.04.02: 468, 1057, 1060, 1061, 1064

Archivo General de Indias, Seville (AGI)

AGI Filipinas 20, n. 2 (found and translated by Ryan Crewe)

\section{Published Primary Sources}

[Chinese]

Changwu zhi 長物志 [Treatise on Superfluous Things]. Compiled by Wen Zhenheng 文震亨. Reprint: Yingyin Wenyuange siku quanshu 景印文淵閣四庫全書, vol. 872. Taipei: Shangwu yinshuguan, 1983.

Chongxiu zhenghe jingshi zhenglei beiyong bencao 重修政和經史證類備用本草 [Newly revised materia medica of the Zhenghe period, annotated, arranged by types, organised for practicality, and based upon the classics and historical works]. Edited by Zhang Cunhui 張存惠, 1249. Reprint: Beijing: Renmin weisheng chubanshe, 1957. https://shuge.org/ebook/zheng-lei-ben-cao/.

Dongxiyang kao 东西洋考. Compiled by Zhang Xie 张焂, 1618. Block print edition preserved in Harvard Yenching Library. https://shuge.org/ebook/dong-xi-yang-kao/.

Jinghetang $j i$ 敬和堂集. Compiled by Xu Fuyuan 许孚远, 1594. Block print edition preserved in Naigakubunko 內閣文庫 (Japan). 
Jufang fahui 局方發揮 [Elaborations on the Pharmacy's Formulary]. Compiled by Zhu Zhenheng 朱震亨, 1347. Reprint, Jin Yuan si dajia yixue quanshu 金元四大家醫學全書. Tianjin: Tianjin kexue jishu chubanshe, 1999.

The Selden Map of China. Bodleian Library, University of Oxford, MS Selden Supra 105. https:// seldenmap.bodleian.ox.ac.uk.

Xiangsheng 香乘 [The Record of Incenses]. Compiled by Zhou Jiazhou 周嘉胄, 1643. Reprint, Yingyin Wenyuange siku quanshu 景印文淵閣四庫全書, vol. 844. Taipei: Shangwu yinshuguan, 1983.

Zhinan zhengfa 指南正法 [The true art of pointing south]. Bodleian Library, University of Oxford.

[Dutch, English, Portuguese, Spanish, and Latin]

Akveld, Leo, ed. Machtsstrijd om Malakka: De reis van VOC-admiraal Cornelis Cornelisz. Matelief naar Oost-Azië, 1605-1608. Zutphen: Walburg Pers, 2013.

Chijs, J. A. van Der, ed. Nederlandsch-Indisch Plakaatboek, 1602-1811. Part 1. Batavia: Landsdrukkerij, 1885.

Colenbrander, H. T., ed. Jan Pietersz. Coen, Bescheiden omtrent zijn bedrijf in Indië. 7 vols. 's-Gravenhage: Martinus Nijhoff, 1919-34.

Coolhaas, W. PH. Generale missiven van gouverneurs-generaal en raden aan Heren XVII der Verenigde Oostindische Compagnie, vol. 1. 's-Gravenhage: Martinus Nijhoff, 1960.

Fletcher, Francis. The World Encompassed by Sir Francis Drake, Being His Next Voyage to That to Nombre de Dios. London: Hakluyt Society, 1856.

Galvão, Antonio. A Treatise on the Moluccas. Translated by Hubert Th. Th. M. Jacobs. Rome: Jesuit Historical Institute, 1971.

"Relação breve da ilha de Ternate, Tydore, e mais ilhas Malucas, aonde temos fortalezas, e presidios, e das forças, naos, e fortalezas, que o enemigo olandes tem por aquelas partes," Malacca, 28 November 1619. In Documentação Ultramarina Portuguesa, vol. 2. Lisbon: Centro de Estudos Historicós Ultramarinos, 1962.

Salva, Miguel, ed. Colección de documentos inéditos para la historia de España, vol. 52. Madrid: Viuda de Calero, 1868.

Selden, John. Mare Clausum seu De dominio maris. London: R. Meighen, 1635.

\section{Secondary Sources}

[Chinese and Japanese]

Blussé, Leonard. "Shouwei fanghe huaren Enpu de zhenmao" 首位訪荷華人恩浦的真貌 [The real visage of the first Chinese in Vlissingen]. Guojia hanghai 國家航海 [National maritime research] vol. 17 (2016): 1-8.

Chen, Tsung-Jen 陳宗仁. “Mr. Selden’s Map youguan Riben de miaohui jiqi zhishi yuanyuan.” Mr. Selden's Map 有關日本的描繪及其知識淵源 [The origin of Japanese shape in Mr. Selden's map]. In Yazhou haiyu jian de xinxi chuandi yu xianghu renshi 亞洲海域間的 信息傳遞與相互認識 [Transmission of information and mutual understanding across the Asian waters], edited by Shiuh-Feng Liu 劉序楓, 341-84. Taipei: Research Centre for Humanities and Social Sciences, Academia Sinica, 2018.

Fan, Ka Wai 范家偉. Beisong jiaozheng yishuju xintan 北宋校正醫書局新探 [A new exploration on the Medical Books Revision Bureau of the Northern Song Dynasty]. Hong Kong: Chung Hwa Book 中華書局, 2014.

Fan, Xingzhun 范行准. Zhongguo yixue shilue 中國醫學史略 [A sketch history of Chinese medicine]. Beijing: Zhongyi Guji Chubanshe 中醫古籍出版社, 1986.

Iwao, Seiichi 岩生成一. “Anboina (Amboina) no shoki Shinamachi ni tsuite”アンボイナ (Amboina) の初期支那町について [On the Chinese quarter at Amboyna in the early days]. Toyo Gakuho 東洋学報 33 (3・4) (1951): 269-311. 
Leung, Angela Ki Che 梁其姿. “Song-Yuan-Ming di difang yiliao ziyuan chutan” 宋元明地地方 醫療資源初探 [A preliminary study on local medical resources of the Song-Yuan-Ming dynasties]. Zhongguo shehui lishi pinglun 中國社會歷史評論 [Review of Chinese social history], 3 (2001): 219-37.

Liu, Jingmin [Liu Ching-Ming] 劉靜敏. Songdai xiangpu zhi yanjiu 宋代《香譜》之研究 [A study of the compendia of incense during the Song period]. Taipei: Wenshizhe chubanshe 文史哲出版社, 2007.

Okamoto, Yoshitomo 岡本良知. Chūsei Morukka Shotō no kōryō 中世モルッカ諸島の香料 [The spices of the Maluku Islands in the Middle Period]. Tokyo: Toyodo 東洋堂, 1944.

Qin, Zhen 秦蓁. “Zhou Jiangzuo Shiji” 周江左事辑 [On the life and achievements of Zhou Jiazhou]. Shilin 史林 5 (2012): 65-74.

Xia, Shihua 夏時華. Songdai xiangyao ye jingji yanjiu 宋代香藥業經濟研究 [A study of the aromatic economy in the Song period]. PhD diss., Shaanxi Normal University, 2012.

Xiang, Da 向達, ed. Liang zhong haidao zhenjing 兩種海道針經 [Two rutters]. Beijing: Zhonghua Shuju 中華書局, 1961.

Xu, Guanmian 徐冠勉. “Qiguai de longduan: Huashang ruhe zai Xiangliao Qundao chengwei Helan Dongyindu Gongsi zuizao de “hezuo huoban' (1560-1620 niandai)” 奇怪的壟斷: 華商如何在香 料群島成為荷蘭東印度公司最早的合作夥伴 (1560-1620 年代) [Strange monopoly: How Chinese merchants became the earliest collaborators of the Dutch East India Company, 1560s1620s]. Quanqiushi pinglun 全球史評論 [Global history review] 12 (2017): 45-85.

Yamada, Kentaro 山田憲太郎. Tōa kōryō shi kenkyu 東亞香料史研究 [A study of the history of perfumery and spices in the Far East]. Tokyo: Chuo-koron Bijutsu Shuppan 中央公論美術出版, 1976.

Yang, Zhishui 揚之水. Xiangshi 香識 [Knowing incense]. Guilin: Guangxi Normal University Press, 2011.

Zhang, Chonggen 張崇根. “Guanyu liang zhong haidao zhenjing de zhuzuoniandai” 關於兩種海 道針經的著作年代 [On the date of the compilation of two rutters]. Studies in the History of the Relations between China and Foreign Countries, vol. 1 (1984): 183-94.

Zhang, Xueqian 张学谦. "Cong Zhu Zhenheng dao Danxi xuepai: Yuan Ming ruyi he yixue xuepai de shehuishi kaocha” 从朱震亨到丹溪学派: 元明儒医和医学学派的社会史考察 [From Zhu Zhenheng to the Danxi School: A social history of the Confucian physician and medical school in late imperial China]. Bulletin of IHP 中央研究院历史语言研究所集刊 86:4 (2015): 777-808.

Zhou, Yunzhong 周運中. "Niujin daxue cang Mingmo Wanlaogao Minshang hanghaitu yanjiu" 牛 津大學藏明末萬老高閩商航海圖研究 [A study of Fujian merchants' Maluku map of the later Ming period collected in Oxford University]. Wenhua zazhi 文化雜誌 87 (2013): 182-94.

[Dutch, English, French, and Portuguese]

Andaya, Leonard Y. "Local Trade Networks in Maluku in the 16th, 17th, and 18th centuries." Cakalele 2:2 (1991): 71-96.

— The World of Maluku: Eastern Indonesia in the Early Modern Period. Honolulu: University of Hawaii Press, 1993.

Batchelor, Robert K. London: The Selden Map and the Making of a Global City, 1549-1689. Chicago: University of Chicago Press, 2014.

Blussé, Leonard. "Chinese Century: The Eighteenth Century in the China Sea Region." Archipel 58 (1999): 107-29.

- "Inpo, Chinese Merchant in Patani: A Study in Early Dutch-Chinese Relations." In Proceedings of the Seventh IAHA Conference, Bangkok 1977, 290-309. Bangkok: Chulalongkorn University Press, 1979.

Borschberg, Peter. Hugo Grotius, the Portuguese and Free Trade in the East Indies. Leiden: KITLV Press, 2011. 
Brixius, Dorit. "A Pepper Acquiring Nutmeg: Pierre Poivre, The French Spice Quest and the Role of Mediators in Southeast Asia, 1740s to 1770s." Journal of the Western Society for French History 43 (2015): 68-77.

Brook, Timothy. The Confusion of Pleasure: Commerce and Culture in Ming China. Berkeley: University of California Press, 1998.

Brooke, Timothy. Mr. Selden's Map of China: Decoding the Secrets of a Vanished Cartographer. New York: Bloomsbury Press, 2013.

Bulbeck, David, et al. Southeast Asian Exports since the 14th Century: Cloves, Pepper, Coffee, and Sugar. Leiden: KITLV Press, 1998.

Cheng, Weichung. "Putchock of India and Radix China: Herbal Exchange around Maritime Asia via the VOC during the 17th and 18th Centuries." Journal of Social Sciences and Philosophy 30:1 (2018): 75-117.

- War, Trade and Piracy in the China Seas, 1622-1683. Leiden: Brill, 2013.

Chia, Lucille. "Of Three Mountain Street: The Commercial Publisher of Ming Nanjing." In Printing and Book Culture in Late Imperial China, edited by Cynthia J. Brokaw and Kai-wing Chow, 107-51. Berkeley: University of California Press, 2005.

- Printing for Profit: The Commercial Publishers of Jianyang, Fujian (11th-17th Centuries). Cambridge, Mass.: Harvard University Press, 2002.

Clunas, Craig. Empire of Great Brightness: Visual and Material Cultures of Ming China, 13681644. Honolulu: University of Hawai'i Press, 2007.

—. Superfluous Things: Material Culture and Social Status in Early Modern China. Honolulu: University of Hawai'i Press, 1991.

Crewe, Ryan. "Transpacific Mestizo: Religion and Caste in the Worlds of a Moluccan Prisoner of the Mexican Inquisition." Itinerario 39 (2015): 463-85.

Elman, Benjamin. "Collecting and Classifying: Ming Dynasty Compendia and Encylopedias (Leishu)." Extrême-Orient, Extrême-Occident, hors série (2007): 131-57.

Finnane, Antonia. Speaking of Yangzhou: A Chinese City, 1550-1850. Cambridge Mass.: Cambridge University Press, 2004.

Goldschmidt, Asaf. "Commercializing Medicine or Benefiting the People: The First Public Pharmacy in China." Science in Context 21: 3 (2008): 311-50.

- The Evolution of Chinese Medicine: Song Dynasty, 960-1200. London: Routledge, 2009.

Goor, Jur van. Jan Pieterszoon Coen, 1587-1629: Koopman-koning in Azië. Amsterdam: Boom, 2015.

Hartwell, Robert M. "Foreign Trade, Monetary Policy and Chinese 'Mercantilism." In Collected Studies on Sung History Dedicated to James T. C. Liu in Celebration of His Seventieth Birthday, edited by Kinugawa Tsuyoshi, 453-88. Kyoto: Dohōsha, 1989.

Hinrichs, T. J. The Medical Transforming of Governance and Southern Customs in Song Dynasty China. PhD diss., Harvard University, 2003.

Ittersum, Martine Julia van. "Debating Natural Law in the Banda Islands: A Case Study in Anglo-Dutch Imperial Competition in the East Indies, 1609-1621." History of European Ideas 42: 4 (2016): 459-501.

- Profit and Principle: Hugo Grotius, Natural Rights Theories and the Rise of Dutch Power in the East Indies, 1595-1615. Leiden: Brill, 2006.

Jung, Dinah. "The Cultural Biography of Agarwood: Perfumery in Eastern Asia and the Asian Neighbourhood.” Journal of the Royal Asiatic Society 23:1 (2013): 103-25.

Knaap, Gerrit. "A City of Migrants: Kota Ambon at the End of the Seventeenth Century." Indonesia 15 (1991): 105-28.

_. "Crisis and Failure: War and Revolt in the Ambon Islands, 1636-1637." Cakalele 3 (1992): $1-26$. 
Kruidnagelen en christenen: De Verenigde Oostindische Compagnie en de bevolking van Ambon, 1656-1696. Leiden: Brill, 2004.

Kogou, Sotiria, et al. "The Origins of the Selden Map of China: Scientific Analysis of the Painting Materials and Techniques using a Holistic Approach." Heritage Science 4:28 (2016): 1-24.

Laurent, Céderic. "Le parfum dans les maisons élégantes sous la dynastie Ming (1368-1644)." In Parfums de Chine: La culture de l'encens au temps des empereurs, edited by Éric Lefebvre. Paris: Musée Cernuschi, 2018.

Leung, Angela Ki Che. "Medical Learning from the Song to the Ming." In The Song-Yuan-Ming Transition in Chinese History, edited by Paul Jakov Smith and Richard von Glahn. Cambridge, Mass.: Harvard University Press, 2003.

Leung, Angela Ki Che, and Ming Chen. "The Itinerary of Hing/Awei/Asafetida across Eurasia, 400-1800." In Entangled Itineraries: Materials, Practices, and Knowledges across Eurasia, edited by Pamela H. Smith. Pittsburgh: University of Pittsburgh Press, 2019.

Leur, J. C. van. Indonesian Trade and Society: Essays in Asian Social and Economic History. The Hague: W. van Hoeve, 1955.

Lobato, Manuel. "Os chineses nas Ilhas Molucas: da prioridade no comércio de longa distância à fixação de uma comunidade residente." In Portugal e a China - Conferências nos Encontros de História Luso-Chinesa, edited by Jorge dos Santos Alves, 147-172. Lisboa: Fundação Oriente, 2001.

Lopez, Ariel C. Conversion and Colonialism: Islam and Christianity in North Sulawesi, c. 17001900. PhD diss., Leiden University, 2018.

Ly-Tio-Fane, Madeleine. Mauritius and the Spice Trade: The Odyssey of Pierre Poivre. Mauritius: Esclapon, 1958.

McDermott, Joseph P. A Social History of the Chinese Book: Books and Literati Culture in Late Imperial China. Hong Kong: Hong Kong University Press, 2006.

Meilink-Roelofsz, M. A. P. Asian Trade and European Influence in the Indonesian Archipelago between 1500 and about 1630. The Hague: Martinus Nijhoff, 1962.

Milton, Giles. Nathaniel's Nutmeg: How One Man's Resolve Changed the World. London: Hodder \& Stoughton, 1999.

Nie, Hongping Annie. The Selden Map of China: A New Understanding of the Ming Dynasty. Bodleian Libraries, University of Oxford, 2014.

Pearson, M. N. "Spain and Spanish Trade in Southeast Asia." Journal of Asian History 2:2 (1968): 109-29.

- Spices in the Indian Ocean World. Aldershot: Variorum, 1996.

Prakash, Om. "Restrictive Trading Regimes: VOC and the Asian Spice Trade in the Seventeenth Century." In Emporia, Commodities and Entrepreneurs in Asian Maritime Trade, ca. 14001750, edited by R. Ptak and D. Rothermund, 107-26. Stuttgart: Steiner Verlag Wiesbaden, 1991.

Prange, Sebastian R. "'Measuring by the Bushel': Reweighing the Indian Ocean Pepper Trade." Historical Research 84:224 (2011): 212-35.

Ptak, Roderich. "China and the Trade in Cloves, Circa 960-1435." Journal of the American Oriental Society 113:1 (1993): 1-13.

—. "The Northern Trade Route to the Spice Islands: South China Sea-Sulu Zone-North Moluccas (14th to Early 16th Century)." Archipel 43 (1992): 27-56.

Sabban, Françoise. "Court Cuisine in Fourteenth-Century Imperial China: Some Culinary Aspects of Hu Sihui's Yinshan Zhengyao." Food and Foodways vol. 1 (1986): 161-96.

Schafer, Edward H. The Golden Peaches of Samarkand: A Study of T'ang Exotics. Berkeley: University of California Press, 1963.

Schrieke, B. Indonesian Sociological Studies, vol. 1. The Hague: W. van Hoeve, 1955.

Shinno, Reiko. The Politics of Chinese Medicine under Mongol Rule. London: Routledge, 2016.

Silva, C. R. de. "The Portuguese and the Trade in Cloves in Asia during the Sixteenth Century."

The Eighth Conference: International Association of Historians of Asia; Selected Papers, edited 
by Mohd Amin Hassan and Nik Hassan, 251-60. Selangor: Universiti Kebangsaan Malaysia, 1988.

So, Jenny F. "Scented Trails: Amber as Aromatic in Medieval China." Journal of the Royal Asiatic Society 23:1 (2013): 85-101.

Szonyi, Michael. The Art of Being Governed: Everyday Politics in Late Imperial China. Princeton, N.J.: Princeton University Press, 2017.

Tremml-Werner, Birgit. Spain, China, and Japan in Manila, 1571-1644. Amsterdam: Amsterdam University Press, 2015.

Villiers, John. "Manila and Maluku: Trade and Warfare in the Eastern Archipelago, 1580-1640." Philippine Studies 34:2 (1986): 146-61.

Widjojo, Muridan. The Revolt of Prince Nuku: Cross-Cultural Alliance-Making in Maluku, c. 1780-1810. Leiden: Brill, 2009.

Yang, Zhishui. "L'encens sous les Song (960-1279) et les Yuan (1279-1368)." In Parfums de Chine: La culture de l'encens au temps des empereurs, edited by Éric Lefebvre. Paris: Musée Cernuschi, 2018.

\section{Notes}

* Guanmian Xu 徐冠勉 (Victor) is a Ph.D. candidate in the Leiden University Institute for Area Studies (LIAS). His Ph.D. project, "Exotic Goods and Chinese Taste: The Global Life of Things in Early Modern Asia, 13001800 " (2017-2021), is generously sponsored by the Ph.D. fellowship of the Hulsewé-Wazniewski Foundation in Leiden.

1 Andaya, The World of Maluku; Milton, Nathaniel's Nutmeg; Villiers, "Manila and Maluku"; Knaap, Kruidnagelen en christenen; Brook, Mr. Selden's Map of China; Widjojo, The Revolt of Prince $\mathrm{Nuku}$; Brixius, "A Pepper Acquiring Nutmeg"; Ly-Tio-Fane, Mauritius and the Spice Trade.

2 Andaya, "Local Trade Networks in Maluku"; Ptak, "The Northern Trade Route to the Spice Islands"; Ptak, "China and the Trade in Cloves"; Pearson, Spices in the Indian Ocean World; Prange, "Measuring by the Bushel"; Bulbeck et al., Southeast Asian Exports, 17-59.

3 Van Leur, Indonesian Trade and Society; Schrieke, Indonesian Sociological Studies.

4 Andaya, "Local Trade Networks in Maluku"; De Silva, "The Portuguese and the Trade in Cloves"; Meilink-Roelofsz, Asian Trade and European Influence; Prange, "Measuring by the Bushel."
5 Meilink-Roelofsz, Asian Trade and European Influence; Prakash, "Restrictive Trading Regimes"; Van Leur, Indonesian Trade and Society; Pearson, "Spain and Spanish Trade in Southeast Asia."

6 Okamoto, Chūsei Morukka Shotō no $k \overline{o r y} \bar{o}$ [The spices of the Maluku Islands] (Thanks to Yu Mengxing from Kyoto University for finding and scanning this book); Yamada, Tōa kōryō shi kenky $\bar{u}$ [A study of the history of perfumery and spices], 318-35; Ptak, "The Northern Trade Route to the Spice Islands"; Ptak, "China and the Trade in Cloves"; Lobato, "Os chineses nas ilhas Molucas"; Zhou, "Niujin daxue cang mingmo wanlaogao minshang hanghaitu yanjiu" [A study of Fujian merchants' Maluku map].

7 The only exceptional case is the article by Lobato, which has attempted to examine the Chinese activities in Maluku well into the seventeenth century, but it has yet to incorporate contemporary Chinese and Dutch sources: Lobato, "Os chineses nas ilhas Molucas".

8 For the relation between the Dutch expansion in Southeast Asia and the legal debate over mare liberum and mare clausum in early seventeenth-century Europe, see Ittersum, Profit and Principle; Ittersum, "Debating Natural Law in the Banda Islands"; Borschberg, Hugo 
Grotius; Brook, Mr. Selden's Map of China, 19-44; Batchelor, London: The Selden Map and the Making of a Global City, 104-51.

9 This point will be nuanced in sections 3, 4 , and 5 in this article. This argument is also inspired by the critical Spanish sources and comments generously offered by Ryan Crewe.

10 Sabban, "Court Cuisine," 177-81.

11 Ibid.

12 Liu, Songdai xiangpu zhi yanjiu [A study of the compendia of incenses during the Song period]; Yang, Xiangshi [Knowing incense]; Yang, "L'encens."

13 Hinrichs, The Medical Transforming of Governance; Goldschmidt, The Evolution of Chinese Medicine; Goldschmidt, "Commercializing Medicine."

14 Fan, Beisong jiaozheng yishuju xintan [A new exploration on the Medical Books Revision Bureau], 239-58; Xia, "Songdai xiangyao ye jingji yanjiu" [A study of the aromatic economy]; Fan, Zhongguo yixue shilue [A sketch history of Chinese medicine], 167-9.

15 A preliminary survey of their occurrences in these recipes was made by Hartwell, see: Hartwell, "Foreign Trade," 475-80. Hartwell translated longnao 龍腦 as Barus camphor, instead of Borneo camphor. There has also been some specific research on the history of individual aromatics; to name just a few: Jung, "The Cultural Biography of Agarwood"; So, "Scented Trails"; Cheng, "Putchock of India and Radix China"; Leung and Chen, "The Itinerary."

16 Schafer, The Golden Peaches of Samarkand.

17 Ibid., 171-2; Ptak, "China and the Trade in Cloves," 4.

18 丁香味辛溫, 無毒, 主溫脾胃, 止霍 亂擁脹, 風毒諸腫, 齒疳蜸, 能發諸 香 Chongxiu zhenghe jingshi zhenglei beiyong bencao [Newly revised materia medica of the Zhenghe period], juan 12, "Guangdong dingxiang" (Canton cloves).

19 Goldschmidt, The Evolution of Chinese Medicine, 112-5; Fan, Beisong jiaozheng yishuju xintan [A new exploration on the Medical Books Revision Bureau], 120 43.

20 The author is working on another paper on the visual representation of these exotica in that survey.

21 Chongxiu zhenghe jingshi zhenglei beiyong bencao [Newly revised materia medica of the Zhenghe period], juan 12, "Guangdong dingxiang" (Canton cloves). The original image in Illustrated Materia Medica (1058-1062 CE) is no longer existent. This figure is from a 13th-century reproduction.

22 Leung, "Song-Yuan-Ming di difang yiliao ziyuan chutan" [A preliminary study]; Shinno, The Politics of Chinese Medicine under Mongol Rule, 82-5.

23 Leung, "Medical Learning from the Song to the Ming," 377-8.

24 Ptak, "China and the Trade in Cloves," 8-9; Ptak, "The Northern Trade Route to the Spice Islands," 29-33.

25 Ptak, "China and the Trade in Cloves," 912; Ptak, "The Northern Trade Route to the Spice Islands," 33-47.

26 Leung, "Song-Yuan-Ming di difang yiliao ziyuan chutan" [A preliminary study].

27 Ibid.

$28 \mathrm{Zhu}$ admonished that well-off people should not be amused by cloves' pleasant scent, while ignoring the long-term harm of their pungent and warm nature. Jufang fahui [Elaborations on the Pharmacy's Formulary], 952. For the history of the school of Zhu, see Zhang Xueqian, "Cong Zhu Zhenheng dao Danxi Xuepai: Yuan Ming ruyi he yixue xuepai de shehuishi kaocha" [From Zhu Zhenheng to the Danxi School].

29 Ptak, "China and the Trade in Cloves," 912; Ptak, "The Northern Trade Route to the Spice Islands," 33-47.

30 Galvão, A Treatise on the Moluccas, 81.

31 For the development of compendia and encyclopaedias in the Ming period, see Elman, "Collecting and Classifying." For a general survey of the place of incense in Ming literati's household, see: Laurent, "Le parfum dans les 
maisons élégantes sous la dynastie Ming."

32 Elman, "Collecting and Classifying"; Chia, "Of Three Mountain Street"; Chia, Printing for Profit; McDermott, A Social History of the Chinese Book.

33 Changwu Zhi [Treatise on Superfluous Things], 12.4a.

34 Clunas, Superfluous Things.

35 Timothy, The Confusion of Pleasure, passim.

36 Finnane, Speaking of Yangzhou, passim; Qin, "Zhou Jiangzuo shiji" [On the life and achievements of Zhou Jiazhou], 65-6.

37 Qin, "Zhou Jiangzuo shiji" [On the life and achievements of Zhou Jiazhou], 65-6.

38 Chia, "Of Three Mountain Street," passim.

39 Clunas, Empire of Great Brightness, 89 90. The painting is titled Nandu fanhui jingwu tu 南都繁會景物圖 [Thriving scene of southern capital] and is preserved in National Museum of China, Beijing.

40 Qin, "Zhou Jiangzuo shiji" [On the life and achievements of Zhou Jiazhou], passim.

41 Ibid., 68-69.

42 Xiangsheng, 18.1b.

43 Dongxiyang kao, 7.1b-2a.

44 Ibid., 7.2b-3a; Cheng, War, Trade and Piracy in the China Seas, 17-32.

45 Dongxiyang kao, 7.14a-b.

46 Ibid., 7.13a.

47 Ibid., 7.15a, 7.16a.

48 Ibid., 7.13a.

49 Ibid., 2.8b, 3.6a, 4.10a

50 Ptak, "The Northern Trade Route to the Spice Islands."

51 Fletcher, The World Encompassed by Sir Francis Drake, 146-7. Many thanks to Tristan Mostert for informing me of this source. It deserves more research indeed.

52 Andaya, The World of Maluku, 136.

53 Jinghetang ji, 7.10a.

54 Bodleian Library, University of Oxford, MS Selden Supra 105.

55 Nie, The Selden Map of China, 19-20; Selden, Mare Clausum, seu De Dominio Maris.
56 To name but a few: Batchelor, London: The Selden Map and the Making of a Global City; Brook, Mr. Selden's Map of China; Kogou et al., "The Origins of the Selden Map of China"; Nie, The Selden Map of China; Zhou, "Niujin daxue cang mingmo wanlaogao minshang hanghaitu yanjiu" [A study of Fujian merchants' Maluku map]; Chen, "Mr. Selden's Map youguan Riben de miaohui" [The origin of Japanese shape in Mr. Selden's map]. Many thanks to Prof. Chen Tsung-Jen for his advice on the latest literature on the Selden Map.

57 According to Brook, Gamalama is the name of the volcanic mountain of Ternate. The Chinese pronounced it as "manlao"/ "wanlao" by dropping the first syllable and adding "gao" at the end in order to indicate this is a tall mountain. Brook, Mr. Selden's Map of China, 125.

58 The date of this manuscript is debated; see Xiang, Liang zhong haidao zhenjing [Two rutters], 3-5; Zhang, "Guanyu liang zhong haidao zhenjing de zhuzuoniandai" [On the date of the compilation of two rutters], 187-93.

59 Each geng is equal to 2.4 hours, and ten geng is equal to one day (24 hours).

60 Zhinan zhengfa, fol. $31 \mathrm{~b}$.

61 The original text on the manuscript is 天相逸, but it could be a typo.

62 Zhinan zhengfa, fol. 32a.

63 Thanks to Alicia Schrikker for inspiring me to take the Sangihe Islands into consideration.

64 Dongxiyang kao, 9.11b.

65 Zhinan zhengfa, fol. 32a.

66 Siau and Oton fell to the Dutch in their expedition launched from Maluku in September 1614, which originally targeted Manila and was led by the governor of Maluku, Laurens Reael. Colenbrander, Coen 1: 126. Dongxiyang kao was published in 1618. How timely Zhang Xie was updated with the situation in Maluku!

67 Dongxiyang kao, 9.12a.

68 Ibid. In the seventeenth century, both the Spanish and the Dutch conceived that the 
control of the Sangihe-Talaud Archipelago was a key to their success in Maluku; see Lopez, Conversion and Colonialism, 136-8.

69 NA, VOC 468: 1, 5 August 1608. This document has been transcribed and published by Leo Akveld as an appendix to Matelief's journal; see Akveld, Machtsstrijd om Malakka, 377-9. Many thanks to Menno Leenstra for informing me of this source.

70 Akveld, Machtsstrijd om Malakka, 199.

71 Ibid., 200.

72 Ibid.

73 Akveld, Machtsstrijd om Malakka, 377.

74 Ryan Crewe very generously offers some highly valuable sources from the Spanish archives. It shows how desperately the Spaniards were dependent on Chinese provisions around this period. In a letter from the general of Maluku to Manila in 1607, it was reported that soldiers at the fort (Fort Rosario, the principal fort of the Spaniards in Maluku) relied on payments of ropa de chincheo (Zhangzhou cloth). The same report mentioned that there were 88 Sangley (Chinese) of all trades present at the fort, but still not enough to meet the fort's needs. Most interestingly, this report mentioned a Sangley ship had arrived, but it only brought 5 of the 74 Sangley construction workers that the general (Juan de Esquivel) had requested. Although with minor discrepancy (74 Chinese workers instead of 75), this account very likely refers to the same shipment of the Chinese junk captured by Matelief in the same year. In the same letter, Esquivel wrote, "there is such a tremendous need that your lordship send us the greatest quantity possible of Sangley masons, so that we proceed to finish [the fort]." "Letter of Juan de Esquivel, maestre de campo [general] of the Moluccas, to the Audiencia of Manila. 1607." AGI Filipinas 20, n. 2: f. 7r; f. 8r-v; f. 9r.

75 Andaya, The World of Maluku, 133; Crewe, "Transpacific Mestizo," 469-70.

76 Andaya, The World of Maluku, 137; Brook, Mr. Selden's Map of China, 124-5.
77 The story was recorded in Dongxiyang $k a o$, and has been recounted by Brook with reference to Spanish sources. Dongxiyang kao, 5.14b-15a; Brook, $M r$. Selden's Map of China, 124-5; Lobato, "Os chineses nas Ilhas Molucas," 159.

78 Andaya, The World of Maluku, 140.

79 Villiers, "Manila and Maluku," 151.

80 Ibid., 160.

81 Pearson, "Spain and Spanish Trade in Southeast Asia," 118-20.

82 Tremml-Werner, Spain, China, and Japan in Manila, 278-82; 284-90.

83 Akveld, Machtsstrijd om Malakka, 377.

84 One quintal is about 100 pounds. The journal of Matelief and the justification of L'Hermite used different accounting units. Whereas the former recorded it as about 500 quintals, the latter counted it as 63 bar. Here the former account is used, because it gives more information such as the price and tax paid by the Chinese. Akveld, Machtsstrijd om Malakka, 200, 378.

85 Ibid.

86 Akveld, Machtsstrijd om Malakka, 200. It is indeed difficult to tell the final destination of the cloves. Crewe insightfully suggests that this shipment of cloves might be destined to Manila for the Spaniards. This is because the Spaniards were bound by the treaty obligation with the Portuguese to keep the clove trade exclusively for the Portuguese, and the native rulers in Maluku were also reluctant to sell cloves to the Spaniards. By using the Chinese as carriers, the Spaniards might be able to get around these restrictions.

87 It refers to Maluku.

88 In this case, the barbarians (yiren 夷人) refer to foreigners in general, and the Dutch and Spaniards in particular.

89 Here, it specifically refers to the Dutch and Iberians.

90 Dongxiyang kao, 5.15b.

91 Xiangsheng, 25.21a.

92 Dongxiyang kao, 5.15b-16a.

93 Ibid. 
94 Crewe offers some highly interesting Spanish accounts that the Chinese in Ternate often had a chance to escape from Dutch fortification and conducted espionage for the Spaniards. Salva, Colección de documentos inéditos para la historia de España, 145, 154, 359, and 360 .

95 Akveld, Machtsstrijd om Malakka, 377.

96 "Relação breve da ilha de Ternate, Tydore, e mais ilhas Malucas," 51; Villiers, "Manila and Maluku," 152.

97 Colenbrander, Coen 1: 82-83.

98 The tension between Coen and Reael regarding Asian traders has been nuanced by Meilink-Roelofsz, Asian Trade and European Influence, 207-38; my own Chinese article has supplemented a few points on this issue: Xu, "Qiguai de longduan" [Strange monopoly], passim.

99 Colenbrander, Coen 1: 82-83.

100 Meilink-Roelofsz, Asian Trade and European Influence, 207-38.

101 Goor, Jan Pieterszoon Coen, 191-8.

102 NA, VOC 1057: 81a, 20 May 1614.

103 NA, VOC 1057: 75a-b, 20 June 1614.

104 NA, VOC 1060: 167, 7 May 1615.

105 Colenbrander, Coen 1: 127-8.

106 NA, VOC 1061: 19a, 6 September 1615; NA, VOC 1061: 20a, 11 September 1615.

107 NA, VOC 1061: 20a, 11 September 1615.

108 NA, VOC 1061: 33b, 7 April 1616.

109 The ship (Swarten Leeuw) carrying that reply would arrive at Banten on 30 April 1616.

110 NA, VOC 1061: 34a, 9 April 1616.

111 Colenbrander, Coen 4: 306-7.

112 Ibid., 311.

113 Reynst passed away in December 1615. On 19 June 1616, Reael was elected by the Council of Indies (in Asia) as his successor.
114 Meilink-Roelofsz, Asian Trade and European Influence, 207-38.

115 Coolhaas, Generale missiven, 72-3; NA, VOC 1064: 8, 10 May 1617.

116 Ibid.

117 NA, VOC 1064: 4b-5a, 10 May 1617.

118 Colenbrander, Coen 4: 353.

119 Ibid., 376-8.

120 Ibid., 379.

121 Der Chijs, Nederlandsch-Indisch Plakaatboek, 45, 50.

122 Ibid., 44.

123 Ibid., 47.

124 Colenbrander, Coen 4: 419-20.

125 Ibid., 421.

126 Colenbrander, Coen 1: 726.

127 Ibid.

128 Ibid.

129 Meilink-Roelofsz, Asian Trade and European Influence, 228.

130 Colenbrander, Coen 1: 726.

131 Andaya, The World of Maluku, passim; Knaap, "Crisis and Failure," passim.

132 Colenbrander, Coen 4: 378.

133 Der Chijs, Nederlandsch-Indisch Plakaatboek, 50.

134 Blussé, "Shouwei fanghe huaren enpu de zhenmao" [The real visage], 2-3.

135 Ibid., 2-4; Blussé, "Inpo," 12.

136 Blussé, "Shouwei fanghe huaren enpu de zhenmao" [The real visage], 5 .

137 Ibid., 4-5.

138 Blussé, "Inpo," 11-2.

139 Ibid.

140 Ibid., 13.

141 Colenbrander, Coen 2: 609.

142 Colenbrander, Coen 2: 652.

143 Knaap, "A City of Migrants," passim; Iwao, "Anboina (Amboina) no shoki shina cho ni tsu i te" [On the Chinese quarter at Amboyna], passim.

144 Szonyi, The Art of Being Governed, 83108.

145 Blussé, "Chinese Century." 